\title{
Fractalkine $\left(\mathrm{CX}_{3} \mathrm{CL} 1\right)$ enhances hippocampal $\mathrm{N}$-methyl-D-aspartate receptor (NMDAR) function via $D$-serine and adenosine receptor type $A 2$ $\left(\mathrm{A}_{2 \mathrm{~A}} \mathrm{R}\right)$ activity
}

Maria Scianni ${ }^{1}$, Letizia Antonilli' ${ }^{1}$, Giuseppina Chece ${ }^{1}$, Gloria Cristalli ${ }^{2}$, Maria Amalia Di Castro ${ }^{1}$, Cristina Limatola ${ }^{1,3^{*}+}$ and Laura Maggi ${ }^{1+}$

\begin{abstract}
Background: N-Methyl-D-aspartate receptors (NMDARs) play fundamental roles in basic brain functions such as excitatory neurotransmission and learning and memory processes. Their function is largely regulated by factors released by glial cells, including the coagonist D-serine. We investigated whether the activation of microglial $\mathrm{CX}_{3} \mathrm{CR} 1$ induces the release of factors that modulate NMDAR functions.

Methods: We recorded the NMDAR component of the field excitatory postsynaptic potentials (NMDA-fEPSPs) elicited in the CA1 stratum radiatum of mouse hippocampal slices by Shaffer collateral stimulation and evaluated D-serine content in the extracellular medium of glial primary cultures by mass spectrometry analysis.

Results: We demonstrated that $\mathrm{CX}_{3} \mathrm{CL} 1$ increases NMDA-fEPSPs by a mechanism involving the activity of the adenosine receptor type $A 2\left(A_{2 A} R\right)$ and the release of the NMDAR coagonist D-serine. Specifically (1) the selective $A_{2 A} R$ blocker 7-(2-phenylethyl)-5-amino-2-(2-furyl)-pyrazolo-[4,3-e]-1,2,4-triazolo[1,5-c]pyrimidine (SCH58261) and the genetic ablation of $A_{2 A} R$ prevent $C X_{3} C L 1$ action while the $A_{2 A} R$ agonist 5-(6-amino-2-(phenethylthio)-9H-purin-9-yl)-N-ethyl-3, 4-dihydroxytetrahydrofuran-2-carboxamide (VT7) mimics CX ${ }_{3} \mathrm{CL} 1$ effect, and (2) the selective blocking of the NMDAR glycine (and D-serine) site by 5,7-dicholorokynurenic acid (DCKA), the enzymatic degradation of D-serine by D-amino acid oxidase (DAAO) and the saturation of the coagonist site by D-serine, all block the $C X_{3} C L 1$ effect. In addition, mass spectrometry analysis demonstrates that stimulation of microglia and astrocytes with $\mathrm{CX}_{3} \mathrm{CL} 1$ or VT7 increases D-serine release in the extracellular medium.
\end{abstract}

Conclusions: $\mathrm{CX}{ }_{3} \mathrm{CL} 1$ transiently potentiates NMDAR function though mechanisms involving $\mathrm{A}_{2 \mathrm{~A}} \mathrm{R}$ activity and the release of D-serine.

Keywords: $\mathrm{CX}_{3} \mathrm{CL} 1$, NMDAR, Microglia, Hippocampus, D-serine, Adenosine receptors

\section{Introduction}

It is now widely accepted that, in addition to their well established role in the immune system, chemokines and their receptors play important roles in the central nervous system (CNS), contributing to the homeostasis of mature brain through neuroendocrine modulation,

\footnotetext{
* Correspondence: cristina.limatola@uniroma1.it

${ }^{\dagger}$ Equal contributors

'Institute Pasteur-Cenci Bolognetti Foundation, Department of Physiology and Pharmacology, University Sapienza, Rome, Italy

${ }^{3}$ IRCCS Neuromed, Pozzilli, Italy

Full list of author information is available at the end of the article
}

neuromodulation and neuroglia communication (for review see [1] and [2]).

Fractalkine $\left(\mathrm{CX}_{3} \mathrm{CL} 1\right)$ is one of the chemokines most abundantly expressed in the brain [3-5], especially by neurons, whereas the only known $\mathrm{CX}_{3} \mathrm{CL} 1$ receptor, $\mathrm{CX}_{3} \mathrm{CR} 1$, is expressed by microglial cells [5-7]. The $\mathrm{CX}_{3} \mathrm{CR} 1 /$ $\mathrm{CX}_{3} \mathrm{CL} 1$ axis plays a major role in neuron/microglia crosstalk and in neuroprotection under conditions of inflammation/injury [5,8-10]. We have previously shown that $\mathrm{CX}_{3} \mathrm{CL} 1$ reduces neuronal death induced by glutamate (Glu) [11] through microglia-derived protective factors 
including adenosine [12,13] and in rodent models of permanent ischemia, exogenous $\mathrm{CX}_{3} \mathrm{CL} 1$ administration is neuroprotective [14]. Moreover, at synapses between Schaffer collaterals and pyramidal neurons in the CA1 region of the hippocampus, $\mathrm{CX}_{3} \mathrm{CL} 1$ exerts a neuromodulatory role inducing $\alpha$-amino-3-hydroxy-5methyl-4-isoxazolepropionic acid receptor (AMPAR)mediated excitatory synaptic depression and negatively modulating long-term potentiation (LTP) mediated by $\mathrm{N}$-methyl-D-aspartate receptors (NMDAR) [15-17].

It is well established that NMDARs play an important role in a variety of physiological and pathological processes such as excitatory neurotransmission, synaptic plasticity and excitotoxicity $[18,19]$. NMDAR function is regulated by agents acting on a number of sites other than the Glu binding site [20], such as glycine [21] and D-serine that act with different affinities on the same binding site [22]. A recent report describes that D-serine preferentially acts on synaptic NMDARs, whereas glycine acts on extrasynaptic NMDARs [23]. In addition, D-serine is highly localized on glia in areas of the brain particularly enriched in NMDARs [24], thus suggesting that these cells are likely playing key roles in regulating NMDAR-dependent processes including synaptic transmission and synaptic plasticity. D-serine is degraded by D-amino acid oxidase (DAAO) and is mainly synthesized from L-serine by serine racemase (SR) present primarily on astrocytes. Recent studies also identified neurons and microglia as other important cellular sources of serine in the brain [25-29] even thought the role of neuronal and microglial D-serine remains to be determined.

Microglia have long been characterized by their innate immune activity in the nervous system, however recent evidence has shed new light on microglia function. These cells are now recognized as full time partners in neuronal function and the crosstalk between neurons and microglia has been described in several physiological and pathological conditions. Microglia secrete a number of factors, including Glu, nitric oxide, purines, trophic and anti-inflammatory substances [30], but also soluble factors affecting NMDAR and AMPAR such as glycine, cytokines, serine proteases and adenosine [31-34]. We have previously shown that stimulation of microglial cells with $\mathrm{CX}_{3} \mathrm{CL} 1$ induces the release of adenosine, which mediates the reduction of AMPAR function [13,15-17], but scarce information is available on specific $\mathrm{CX}_{3} \mathrm{CL} 1$ effects on hippocampal NMDARs [35] that are highly involved in synaptic plasticity processes.

In the present work we demonstrate that $\mathrm{CX}_{3} \mathrm{CL} 1$ modulates NMDA-mediated synaptic transmission in the hippocampal CA1 region, through the activity of the $A_{2 A} R$ and the release of $D$-serine from glia.

\section{Methods}

\section{Animals}

Experiments were performed in agreement with international guidelines on the ethical use of animals from the European Communities Council Directive of 24 November 1986 (86/609 EEC). Hippocampal slices were routinely obtained from 1-month-old C57BL/6. When specified, hippocampal slices were obtained from gene modified animals: (1) $\mathrm{CX}_{3} \mathrm{CR} 1^{\mathrm{GFP} / \mathrm{GFP}}$ mice on the C57BL/6 background (from Charles River, Calco, Italy), that were generated by replacing the first $390 \mathrm{bp}$ of the $C X_{3} C R 1$ gene with the EGFP gene [6,36]; (2) $\mathrm{A}_{1} \mathrm{R} K \mathrm{KO}$ mice [37] and (3) $\mathrm{A}_{3} \mathrm{RKO}$ mice [38] backcrossed at least ten times on a C57BL/6 background; (4) $\mathrm{A}_{2}$ knockout mice [39] on a BALB/cJ background $\left(\mathrm{C} ; 129 \mathrm{~S}-\right.$ Adora $\left.2 a^{\text {tmlIffc }} / \mathrm{J}\right)$ and control $\mathrm{BALB} / \mathrm{cJ}$ wild-type mice (Charles River, Calco, Italy). C57BL/6 and BALB/cJ wild-type mice showed similar responses to $\mathrm{CX}_{3} \mathrm{CL} 1$ application (not shown).

\section{Hippocampal slice preparation}

Briefly, animals were decapitated after being anesthetized with halothane. Whole brains were rapidly removed from the skull and immersed for 10 minutes in ice-cold artificial cerebrospinal fluid (ACSF) solution containing (1) for field recording experiments (in $\mathrm{mM}$ ): $\mathrm{NaCl} 125, \mathrm{KCl} 4.4, \mathrm{CaCl}_{2}$ 2.5, $\mathrm{MgSO}_{4}$ 1.5, $\mathrm{NaHPO}_{4} 1, \mathrm{NaHCO}_{3} 26$ and glucose 10; (2) for patch clamp recordings (in $\mathrm{mM}$ ): $\mathrm{NaCl} 125, \mathrm{KCl}$ 2.5, $\mathrm{NaH}_{2} \mathrm{PO}_{4} 1.25, \mathrm{NaHCO}_{3} 26, \mathrm{CaCl}_{2} 2, \mathrm{MgCl}_{2} 1$, and glucose 10 . The ACSF was continuously oxygenated with $95 \% \mathrm{O}_{2}, 5 \% \mathrm{CO}_{2}$ to maintain the proper $\mathrm{pH}$ (7.4). Transverse ( 250 or $350 \mu \mathrm{m}$ thick) slices were cut at $4^{\circ} \mathrm{C}$ with a vibratome (DSK, Japan) and the slices were placed in a chamber containing oxygenated ACSF. After their preparation, slices were allowed to recover for $1 \mathrm{~h}$ before recording.

For field recording experiments individual slices $(350 \mu \mathrm{m}$ thick) were then transferred to the interface slice-recording chamber (BSC1, Scientific System Design Inc., Mississauga, Ontario, Canada) with a total fluid dead space of approximately $3 \mathrm{ml}$. Slices were maintained at 30 to $32^{\circ} \mathrm{C}$ and constantly superfused at the rate of $2 \mathrm{ml} / \mathrm{min}$. Solutions were applied to the slices by a peristaltic pump.

For patch-clamp experiments, individual slices $(250 \mu \mathrm{m}$ thick) were submerged in ACSF in the recording chamber at room temperature. The ACSF was perfused at a rate of approximately $1 \mathrm{ml} / \mathrm{min}$.

In all experiments, unless otherwise specified, to isolate the NMDAR component, a modified ACSF (M-ACSF) containing low $\mathrm{Mg}^{2+}$ concentration $\left(\mathrm{MgSO}_{4}\right.$ or $\mathrm{MgCl}_{2}$ were reduced to $0.2 \mathrm{mM}$ ) and the AMPA receptor blocker 2,3-dihydroxy-6-nitro-7-sulfamoyl-benzo[f]quinoxaline-2,3dione (NBQX; $10 \mathrm{mM}$ ) were perfused for at least 20 minutes. 


\section{Field potential recording}

Slices were visualized with a Wild M3B microscope (Heerbrugg, Switzerland). At the beginning of each recording, a concentric bipolar stimulating electrode (SNE-100X $50 \mathrm{~mm}$ long Elektronik-Harvard Apparatus $\mathrm{GmbH}$, Crisel Instruments, Rome Italy) was positioned in the stratum radiatum for stimulation of Schaffer collateral pathway projections to CA1. An ACSF-filled glass micropipette (0.5 to $1 \mathrm{M} \Omega$ ) was positioned 200 to $600 \mu \mathrm{m}$ from the stimulating electrode for recording the orthodromically-evoked NMDAR component of field excitatory postsynaptic potentials (NMDA-fEPSPs). Stimuli consisted of 100- $\mu$ s-long constant current square pulses, applied at $0.05 \mathrm{~Hz}$. The intensity of the stimulus was adjusted in each experiment to evoke approximately $50 \%$ of the maximal field potential amplitude without appreciable population spike contamination. Evoked responses were monitored online and stable baseline responses were recorded for at least 10 minutes. Only the slices that showed stable NMDA-fEPSP amplitudes were included in the experiments. To analyze the timecourse of the NMDA-fEPSPs slope, the recorded NMDA-fEPSPs were routinely averaged over 1 minute $(\mathrm{N}=3)$. Experiments were performed in M-ACSF and averaged NMDA-fEPSPs (last 5 minutes of treatment or washout) were normalized to baseline values ( 5 minutes) prior to treatment. In the text, $\mathrm{n}$ refers to the number of slices analyzed/number of mice.

For the paired-pulse ratio (PPR) test, closely spaced consecutive stimuli (50 ms interval) were used, and PPR was calculated as the ratio between the NMDA-fEPSPs amplitude evoked by the second stimulus (A2) over the first (A1; A2/A1).

NMDA-fEPSPs were recorded and filtered $(1 \mathrm{kHz})$ with an Axopatch $200 \mathrm{~A}$ amplifier (Axon Instruments, CA, USA) and digitized at $10 \mathrm{kHz}$ with an A/D converter (Digidata 1322A, Axon Instruments). Data were stored on a computer using pClamp 9 software (Axon Instruments) and analyzed offline with the Clampfit 9 program (Axon Instruments).

\section{Patch-clamp recordings}

Neurons were visualized at $640 \times$ with Nomarski optics with an upright Zeiss (Thornwood, NY, USA) Axioscope microscope. Patch-clamp recordings were obtained using glass electrodes ( 3 to $4 \mathrm{M} \Omega$ ) filled with the following (in $\mathrm{mM}$ ): $\mathrm{CsMeSO}_{4} 135, \mathrm{CsCl} 4, \mathrm{MgCl}_{2}$ 2, 2-[4-(2hydroxyethyl)piperazin-1-yl]ethanesulfonic acid (HEPES) 10, MgATP 2, NaGTP 0.3, (1,2-bis(o-aminophenoxy)ethane- $N, N, N^{\prime}, N^{\prime}$-tetraacetic acid (BAPTA) $5(\mathrm{pH} 7.3$, with $\mathrm{CsOH}$ ). Neurons were clamped at $-70 \mathrm{mV}$ and perfused with M-ACSF. NMDA currents in standard ACSF were recorded at positive potential to remove $\mathrm{Mg}$ block (10 $\mathrm{mV}$ ) using the following solution (in $\mathrm{mM}$ ): $\mathrm{CsCl} 130$,
$\mathrm{MgCl}_{2}$ 2, HEPES 10, MgATP 2, NaGTP 0.3, BAPTA 5 (pH 7.3, with $\mathrm{CsOH}$ ).

Membrane currents, recorded with a patch-clamp amplifier (Axopatch 200A; Molecular Devices, Foster City, CA, USA), were filtered at $2 \mathrm{kHz}$, digitized $(10 \mathrm{kHz})$, and acquired with pClamp 9 software (Molecular Devices, Sunnyvale CA, USA). Excitatory postsynaptic currents (EPSCs) were evoked in CA1 pyramidal neurons by electrical stimulation with theta glass tubes pulled to a final tip diameter of 10 to $20 \mu \mathrm{m}$ and filled with external solution. Stimulating electrodes were placed in the stratum radiatum to activate the Schaffer collateral pathway projecting to CA1. NMDA-EPSCs were evoked by stimulating at 5 to $50 \mathrm{~V}$ for 150 to $300 \mu \mathrm{s}$ every $20 \mathrm{~s}$. Recorded EPSCs were routinely averaged over 1 minute $(\mathrm{N}=3)$ to analyze the timecourse of EPSC amplitude. Averaged NMDA-EPSCs (last 5 minutes of treatment or washout) were normalized to baseline values ( 5 minutes) prior to treatment. Stable EPSCs were monitored for at least 10 minutes before applying $\mathrm{CX}_{3} \mathrm{CL} 1$ and successively monitored during slice exposure to $\mathrm{CX}_{3} \mathrm{CL1}$ ( $5 \mathrm{nM}$, a concentration close to the IC50 value for synaptic depression of AMPA mediated responses and to the concentration that inhibits NMDA-dependent LTP [15-17]. Data were analyzed offline with Clampfit 9 (Axon Instruments).

\section{Glia and neuron primary cultures}

Primary cortical glial cells were prepared from 0 to 2-day-old mice. Cerebral cortices were chopped and digested in $30 \mathrm{U} / \mathrm{ml}$ papain for 40 minutes at $37^{\circ} \mathrm{C}$ followed by gentle trituration. The dissociated cells were washed, suspended in Dulbecco's modified Eagle medium (DMEM) with $10 \%$ fetal bovine serum (FBS) (Invitrogen, Life Technologies, Monza, Italy) and $2 \mathrm{mM}$ L-glutamine and plated at a density of 9 to $10 \times 10^{5}$ in $175 \mathrm{~cm}^{2}$ cell culture flasks. At confluence (11 days in vitro), glial cells were plated $\left(5.0 \times 10^{5} \mathrm{cells} / \mathrm{cm}^{2}\right)$ on dishes coated with poly-Llysine $(100 \mu \mathrm{g} / \mathrm{ml})$ in DMEM supplemented with $10 \%$ FBS, $100 \mathrm{U} / \mathrm{ml}$ penicillin, $0.1 \mathrm{mg} / \mathrm{ml}$ streptomycin. To detach and collect microglial cells, glial cells at confluence (11 days in vitro) were shaken for $2 \mathrm{~h}$ at $37^{\circ} \mathrm{C}$. These procedures gave almost pure microglia $(<2 \%$ astrocyte contamination) and astrocytes cell population (4\% to $6 \%$ of microglia contamination), as verified by staining for glial fibrillary acidic protein (GFAP) and isolectin $\mathrm{IB}_{4}$.

Cortical neuronal cultures were prepared from newborn C57BL/6 mice (P0 to P1). Cerebral cortex were chopped and digested in $20 \mathrm{U} / \mathrm{ml}$ papain for 40 minutes at $37^{\circ} \mathrm{C}$. Cells $\left(13 \times 10^{4}\right.$ cells $\left./ \mathrm{cm}^{2}\right)$ were plated on dishes coated with poly-L-lysine $(100 \mu \mathrm{g} / \mathrm{mL})$ in basal medium Eagle (BME) supplemented with $1 \mathrm{mM}$ sodium pyruvate, $30 \mathrm{mM}$ glucose, $0.1 \%$ Mito $^{\mathrm{Tm}}$ serum extender, $10 \% \mathrm{FBS}$, $100 \mathrm{U} / \mathrm{mL}$ penicillin, $0.1 \mathrm{mg} / \mathrm{mL}$ streptomycin and $10 \mathrm{mM}$ HEPES- $\mathrm{NaOH}$ ( $\mathrm{pH}$ 7.4). After $4 \mathrm{~h}$ the medium was 
changed with Neurobasal medium supplemented with $1 \mathrm{mM}$ glutamine, $0.1 \% \mathrm{Mito}^{\mathrm{Tm}}$ serum extender, $2.5 \% \mathrm{~B} 27$, $100 \mathrm{U} / \mathrm{ml}$ penicillin and $0.1 \mathrm{mg} / \mathrm{mL}$ streptomycin. After 2 days, AraC $(5 \mu \mathrm{M})$ was added to avoid the growth of glial cells. The percentage of neuronal cells obtained is $80 \%$ to $90 \%$, as determined with $\beta$-tubulin III staining. Cultures were used after 10 to 11 days.

\section{Measurement of D-serine by liquid chromatography and mass spectrometry (MS) analysis}

Mixed glia, microglia and neuronal cultures at 11 days old were pretreated in M-ACSF for 40 minutes and stimulated for either 20 minutes, $2 \mathrm{~h}$ and 20 minutes and $4 \mathrm{~h}$ with $\mathrm{CX}_{3} \mathrm{CL} 110 \mathrm{nM}$ or vehicle. After this time, media were collected, centrifuged at $4^{\circ} \mathrm{C}$ for 10 minutes at high speed, and the resulting supernatants were kept to $-20^{\circ} \mathrm{C}$ until use. Cells remaining in the dish were analyzed for protein content with a BCA assay (Pierce, Euroclone Pero, Italy).

Aliquots of the culture medium was derivatized according to the method described by Berna and Ackermann [40]. Briefly, samples ( $25 \mu \mathrm{l})$ were incubated with $200 \mathrm{mM}$ (pH 7.5) sodium bicarbonate solution and $10 \mu \mathrm{l}$ of $1 \%$ Marfey's reagent (w/v in acetone) at $60^{\circ} \mathrm{C}$ for $1 \mathrm{~h}$.

Next, the samples were evaporated to dryness at $60^{\circ} \mathrm{C}$ under a stream of nitrogen, and the dried residues were reconstituted with $12.5 \%$ methanol in $15 \mathrm{mM}$ ammonium acetate. The samples were centrifuged at $600 \mathrm{~g}$ for 5 minutes and the supernatants diluted with $200 \mu$ of mobile phase. Injections of $20 \mu \mathrm{l}$ were performed for liquid chromatography-tandem mass spectrometry (LC-MS/MS) analysis. Marfey's adducts of D standard mixture were prepared by appropriate dilution of the $100 \mu \mathrm{g} / \mathrm{ml}$ stock solution of D-serine in highperformance liquid chromatography (HPLC)-grade water and following the same derivatization procedure.

The LC-MS/MS system consisted of a PerkinElmer 200 Series binary pump and autosampler (PerkinElmer, Norwalk, CT, USA) and an SCIEX API2000MS/MS triple quadrupole mass spectrometer including a Turbolon Spray ${ }^{\circledR}$ ionization source (Applied BiosystemMDS SCIEX, Thornhill, Ontario, Canada).

Chromatographic separation was performed on a Synergi Polar RP column $(150 \times 2.0 \mathrm{~mm}, 4 \mu \mathrm{m})$, protected by a guard column with identical packing material $(4 \times$ $2.0 \mathrm{~mm}$; Phenomenex, Torrance, CA, USA) The mobile phase consisted of a linear gradient (30\% to $70 \%$ with respect to acetonitrile) formed by combination of $5 \mathrm{mM}$ ammonium formate buffer in water ( $\mathrm{pH} 4.0$, eluent $\mathrm{A})$ and acetonitrile (eluent B) at a flow rate of $0.2 \mathrm{ml} / \mathrm{min}$.

D-Serine derivatives were detected using multiple reaction monitoring (MRM) in negative ionization mode. Selected ion masses of the protonated precursors and fragmented ions $(\mathrm{m} / \mathrm{z})$ were $359.1>192$. Chromatographic peaks were integrated using Analyst ${ }^{\mathrm{im}}$ software (version 1.4.1, SCIEX). The detection limits (LOD) and quantification limits (LOQ) for D-serine were $1.71 \mathrm{ng} / \mathrm{ml}$ and $5.18 \mathrm{ng} / \mathrm{ml}$ respectively. The Marfey's derivated isobaric compounds L-Ser and D-Ser (2,4-dinitro-phenyl-5-Lalanine amide- (DNPA-)L-Ser and DNPA-D-Ser) were well resolved chromatographically as shown in Additional file 1: Figure S1. An example of the blank samples (control $\mathrm{M}$-ACSF) is shown in Additional file 2: Figure S2, where no signal corresponding to DNPA-L-Ser or DNPA-D-Ser are present.

\section{Statistical analysis}

The values were reported as mean \pm SEM. Unless otherwise specified, data values refer to number of slices/ number of animals analyzed. Where appropriate, $t$ tests or one-way analysis of variance (ANOVA) were used. Since in all experiments data passed the normality and the equal variance tests, we performed parametric ANOVA followed by Tukey or Holm-Sidak multiplecomparison test (Sigma Plot, 11.0 software). If not specified, $P$ values refer to ANOVA post hoc analyses.

\section{Drugs}

$\mathrm{CX}_{3}$ CL1 (human, Peprotech Inc. Rocky Hill, NJ, USA), 7(2-phenylethyl)-5-amino-2-(2-furyl)-pyrazolo-[4,3-e]-1,2,4triazolo[1,5-c]pyrimidine (SCH58261, stock solution $10 \mathrm{mM}$ in dimethylsulfoxide (DMSO)), triazoloquinazoline (CGS15943, stock solution $5 \mathrm{mM}$ in DMSO) and 1, 3-dipropyl-8-cyclopentylxanthine (DPCPX stock solution $5 \mathrm{mM}$ in DMSO) by Tocris Bioscience, Bristol, UK. 3Propyl-6-ethyl-5-[(ethylthio)carbonyl]-2 phenyl-4-propyl-3-pyridine carboxylate (MRS1523, stock solution 10 $\mathrm{mM})$, catalase, D-amino acid oxidase (DAAO), Marfey's reagent (No-(2,4-dinitro-5-fluophenyl)-L-alaninamide), ammonium formate and Minocycline (stock solution 20 $\mathrm{mM}$ ) from Sigma-Aldrich (Milan, Italy). NBQX (stock solution $20 \mathrm{mM}$ ), 5,7-dicholorokynurenic acid (DCKA, stock solution $750 \mu \mathrm{M}$ in 1 eq. $\mathrm{NaOH}$ ) and D-serine (stock solution $10 \mathrm{mM}$ ) by Ascent Scientific, Bristol, UK. 5-(6Amino-2-(phenethylthio)-9H-purin-9-yl)- $N$-ethyl-3,4 -dihydroxytetrahydrofuran-2-carboxamide (VT7, stock solution $10 \mathrm{mM}$ in DMSO). Adenosine deaminase (ADA, Roche, Germany). Acetonitrile, methanol, both gradient grades were purchased from Merck (Darmstadt, Germany). Ultrapure water was prepared using a Millu-Q system (Millipore, MA, USA).

Drugs were dissolved in ACSF just before application.

\section{Results}

$\mathrm{CX}_{3} \mathrm{CL} 1$ increases hippocampal NMDA responses

To investigate whether $\mathrm{CX}_{3} \mathrm{CL} 1$ influences NMDAmediated synaptic transmission in hippocampal CA1 
region, we recorded the NMDAR component of the fEPSPs (NMDA-fEPSPs) elicited in the CA1 stratum radiatum of mouse hippocampal slices by electrical stimulation of the Schaffer collateral (at $0.05 \mathrm{~Hz}$ ). To isolate the NMDA component of the fEPSPs slices were treated with the AMPA receptor blocker NBQX $(10 \mu \mathrm{M})$ and with low $(0.2 \mathrm{mM})$ magnesium [41]. In control slices, synaptic activity was stable for at least 30 minutes (not shown). We challenged the slices with $\mathrm{CX}_{3} \mathrm{CL} 1$ at concentrations of $5 \mathrm{nM}$. In the majority of the experiments ( 25 out of 35 slices tested, 28 mice; Figure 1A) bath application of $\mathrm{CX}_{3} \mathrm{CL} 1$ for $20 \mathrm{mi}-$ nutes induced a short-term potentiation (STP) of synaptic transmission. The potentiation of the NMDA-fEPSPs slope developed within 5 minutes of $\mathrm{CX}_{3} \mathrm{CL} 1$ application was $1.22 \pm 0.03$ of baseline (from 1.92 to 1.01 in different experiments, measured here and thereafter after 20 minutes of treatment, $P<0.05$ ) and was followed by partial recovery (to $1.15 \pm 0.01$ of baseline, $P<0.05$, measured here and thereafter at 20 minutes of $\mathrm{CX}_{3} \mathrm{CL} 1$ withdrawal) with a few exceptions where full recovery was observed. To exclude the possibility that $\mathrm{CX}_{3} \mathrm{CL} 1$ treatment induces a change in presynaptic cell excitability, such as the recruitment of more presynaptic fibers by the same stimulus, changes in the amplitude of extracellular fiber volley (an index of presynaptic excitation) were monitored by recording evoked fEPSPs during $\mathrm{CX}_{3} \mathrm{CL} 1$ application. As shown in Additional file 3: Figure S3A, in a subset of slices where the potentiating effect of $\mathrm{CX}_{3} \mathrm{CL} 1$ was maximal (41.68 \pm 0.05 of baseline, $\mathrm{n}=5, P<0.05)$ the amplitude of the afferent volley did not change after treatment with $\mathrm{CX}_{3} \mathrm{CL} 1(P=0.45$, paired $t$ test $)$.

Patch-clamp experiments were carried out to measure $\mathrm{CX}_{3} \mathrm{CL} 1$-mediated modulation of NMDA current at the single cell level. Whole-cell recordings of NMDAEPSCs were performed in CA1 pyramidal neurons in acute slices while repeatedly stimulating Schaffer collateral axons. $\mathrm{CX}_{3} \mathrm{CL} 1$ treatment caused an increase in NMDA-EPSC peak amplitude (to $1.25 \pm 0.03 P<0.05$ vs baseline) that recovered upon withdrawal (to $1.06 \pm$ $0.04 P>0.05$ vs baseline, Figure $1 \mathrm{~B}$, five slices/five mice). These results confirmed the $\mathrm{CX}_{3} \mathrm{CL} 1$-mediated potentiation of NMDA responses also at the single cell level.

\section{Paired pulse facilitation (PPF) ratio is not altered by $\mathrm{CX}_{3} \mathrm{CL} 1$ application}

To analyze if $\mathrm{CX}_{3} \mathrm{CL} 1$ potentiates NMDA-fEPSPs by altering presynaptic glutamate release, we performed studies of short-term plasticity, that is, paired-pulse ratio (PPR) measurements. The PPR, which is the ratio of the amplitude of the second response vs the first, depends on the probability of vesicular release at synapse and its variation is generally associated with changes in transmitter release probability [42].

To evaluate PPR values we stimulated Schaffer collateral pathway projections to CA1 at $50 \mathrm{~ms}$ intervals. As shown in Additional file 3: Figure S3B, PPR was $1.53 \pm 0.017$ and $1.54 \pm 0.026$ before and after $20 \mathrm{~min}$ of $\mathrm{CX}_{3} \mathrm{CL} 1$ treatment (6 slices $/ 4$ mice, $P=0.74$, paired $t$ test), respectively.

Presynaptic release of Glu can be affected by removal of $\mathrm{Mg}^{2+}$ from the external solution, changing the competition between $\mathrm{Mg}^{2+}$ and $\mathrm{Ca}^{2+}$ at terminal endings and altering PPR mechanisms [43]. To investigate this possibility we repeated the PPR measurements in whole-cell experiments where the NMDA current were isolated by depolarizing the cell in a standard ACSF medium. As shown in Additional file 3: Figure S3C, the PPR measured in this
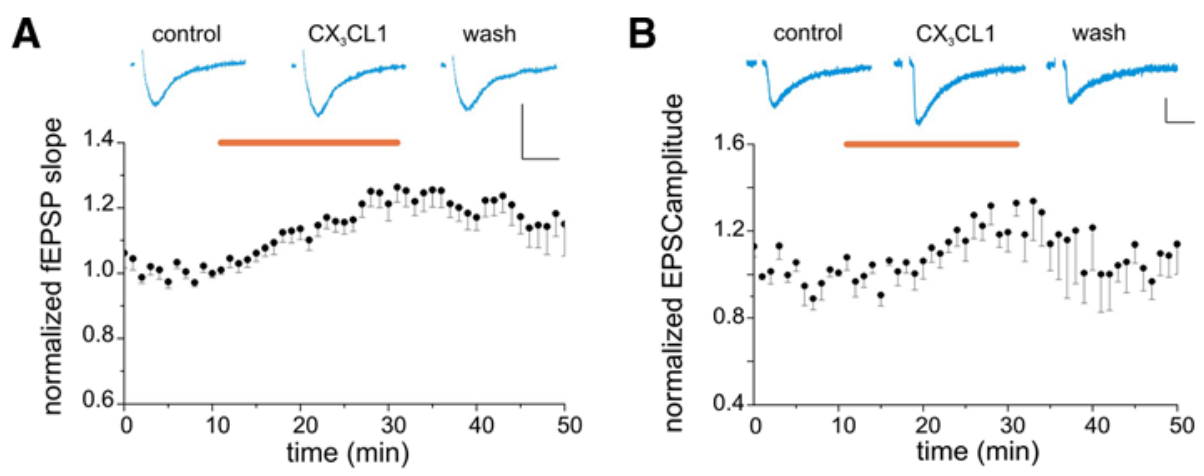

Figure $1 \mathrm{CX}_{3} \mathrm{CL} 1$ produces transient $\mathrm{N}$-methyl-D-aspartate receptor (NMDAR) potentiation in CA1 pyramidal neurons (STP). Horizontal bar, $\mathrm{CX}_{3} \mathrm{CL} 1$ application (5 nM). (A) CX $\mathrm{X}_{3} \mathrm{CL} 1$ increases NMDA-field excitatory postsynaptic potentials (fEPSPs) slope. Top: representative average traces of NMDA-fEPSPs recorded in control (1 minute before application), after 20 minutes of $C X_{3} C L 1$ treatment and at 20 minutes of withdrawal, as indicated. Vertical scale bar: $0.2 \mathrm{mV}$, horizontal scale bar: $20 \mathrm{~ms}$. Bottom: average timecourse of CX ${ }_{3}$ CL1-induced increase of the NMDA-fEPSPs slope in mouse hippocampal slices $(n=35 / 28)$. Here and thereafter each point represents the average of three responses evoked every 20 s, as detailed in Methods. (B) $\mathrm{CX}_{3} \mathrm{CL} 1$ increases the amplitude of evoked excitatory postsynaptic currents (EPSCs). Top: sample traces of EPSCS (average of three events over 1 minute) recorded before, after 20 minutes of chemokine application, and 20 minutes after washout, as indicated. Vertical scale bar: 20 pA, horizontal scale bar: 20 ms. Bottom: average timecourse of the current peak amplitude. Circles represent averages of three responses evoked every $20 \mathrm{~s}$ in five different slices (five mice). 
condition was $1.43 \pm 0.08$ and $1.44 \pm 0.09$ before and after 20 minutes of $\mathrm{CX}_{3} \mathrm{CL} 1$ treatment, (5 slices/5 mice, $P=0.81$, paired $t$ test). These data indicated that under our experimental conditions, $\mathrm{CX}_{3} \mathrm{CL} 1$ treatment did not cause obvious changes in presynaptic release probability, confirming the postsynaptic nature of the potentiation of NMDA-fEPSPs, in line with our previous findings $[15,44]$.

\section{$\mathrm{CX}_{3} \mathrm{CL} 1$-mediated effects require the presence of $\mathrm{CX}_{3} \mathrm{CR} 1$ on microglial cells}

To demonstrate that the effects of $\mathrm{CX}_{3} \mathrm{CL} 1$ were indeed mediated by $\mathrm{CX}_{3} \mathrm{CR} 1$, experiments were performed on $\mathrm{CX}_{3} \mathrm{CR} 1^{\mathrm{GFP} / \mathrm{GFP}}$ mice where the murine $\mathrm{CX}_{3} \mathrm{CR} 1$ gene was replaced with the cDNA encoding EGFP (Jung et al. [6]). Application of $\mathrm{CX}_{3} \mathrm{CL} 1$ for 20 minutes to $\mathrm{CX}_{3} \mathrm{CR} 1^{\mathrm{GFP} / \mathrm{GFP}}$ hippocampal slices (Figure 2A, seven slices/three mice) failed to induce any obvious basal NMDA-fEPSPs slope change $(P>0.05)$. These findings clearly show that $\mathrm{CX}_{3} \mathrm{CL} 1$-induced effects on NMDA-fEPSPs were mediated through $\mathrm{CX}_{3} \mathrm{CR} 1$ activation.

Since $\mathrm{CX}_{3} \mathrm{CR} 1$ is expressed on microglial cells $[5,6]$, we wondered whether microglial activation was required for $\mathrm{CX}_{3} \mathrm{CL} 1$-mediated STP of NMDA-fEPSPs. For this purpose we treated hippocampal slices with a broadspectrum tetracycline antibiotic, minocycline, known to inhibits microglial activation [45-47].

As shown in Figure 2B, in the presence of minocycline (20 $\mu \mathrm{M}, 1 \mathrm{~h}$ preincubation), the application of $\mathrm{CX}_{3} \mathrm{CL} 1$ did not significantly affect the NMDA-fEPSPs $(P>0.5$, eight slices/two mice), demonstrating a microglia-driven chemokine effect.

\section{$\mathrm{CX}_{3} \mathrm{CL} 1$-mediated NMDAR potentiation is mediated by ARs}

We have previously shown that $\mathrm{CX}_{3} \mathrm{CL} 1$ treatment induces the release of adenosine from microglia [12] and that $\mathrm{CX}_{3}$ CL1-mediated modulation of synaptic transmission and plasticity involves AR activity [17,48]. In addition, it is known that AR activity in the hippocampus modulates NMDA receptor functioning [49]. For all these reasons we investigated whether $\mathrm{CX}_{3} \mathrm{CL} 1$ effects on NMDARs require AR activity. We first treated hippocampal slices with the broad-spectrum AR antagonist CGS15943. The applications of CGS15943 $(1 \mu \mathrm{M})$ abolished $\mathrm{CX}_{3}$ CL1-mediated STP of NMDA-fEPSPs (Figure 3A, $P>0.05$ vs baseline, nine slices/four mice) indicating that the activity of ARs is indeed involved in $\mathrm{CX}_{3} \mathrm{CL} 1$ effects.

To disclose the specific role of distinct AR subtypes, we performed additional experiments with selective $A_{1} R$, $A_{2 A} R$ and $A_{3} R$ antagonists (Figure 3B-D).

Specifically, the $A_{1} R$ antagonist DPCPX $(25 \mathrm{nM})$ failed to prevent $\mathrm{CX}_{3} \mathrm{CL} 1$-mediated modulation of NMDAR, as the NMDA-fEPSPs slope increased during $\mathrm{CX}_{3} \mathrm{CL} 1$ treatment (to $1.25 \pm 0.01, P<0.05$ vs baseline, $P>0.05$ vs $\mathrm{CX}_{3} \mathrm{CL} 1$ alone) and remained high upon withdrawal (to $1.25 \pm 0.04 P<0.05$ vs baseline, Figure 3B, nine slices/five mice). Similarly, the specific $A_{3} R$ antagonist MRS1523 $(100 \mathrm{nM})$ was unable to affect the action of $\mathrm{CX}_{3} \mathrm{CL} 1$ that elicited a significant increase in NMDA-fEPSPs slope (to $1.23 \pm 0.01, P<0.05$ vs baseline, $P>0.05$ vs $\mathrm{CX}_{3} \mathrm{CL} 1$ alone) partially recovering upon withdrawal (1.12 \pm 0.01 , $P<0.05$ vs baseline, Figure 3C, ten slices/five mice).

Conversely, when slices were treated with the selective $\mathrm{A}_{2 \mathrm{~A}} \mathrm{R}$ antagonist $\mathrm{SCH} 58261$ (10 nM), CX ${ }_{3} \mathrm{CL} 1$ was unable to affect NMDA-fEPSPs slope (Figure 3D, $P>0.05$ vs baseline $P<0.01$ vs $\mathrm{CX}_{3} \mathrm{CL} 1$ alone, six slices/three mice), indicating that $\mathrm{A}_{2 \mathrm{~A}} \mathrm{R}$ activity is associated with $\mathrm{CX}_{3} \mathrm{CL} 1$ effects on NMDAR-dependent basal transmission.

The role of ARs in $\mathrm{CX}_{3} \mathrm{CL} 1$ effects was further investigated by means of mice selectively lacking AR subtypes. As shown in Figure 4A application of $\mathrm{CX}_{3} \mathrm{CL} 1$ in $\mathrm{A}_{1} \mathrm{R}^{-/-}$mice increased NMDA-fEPSPs slope (to $1.14 \pm$ $0.01, P<0.05$ vs baseline) that partially recovered after washout (to $1.04 \pm 0.02, P>0.05$ vs baseline, ten slices/
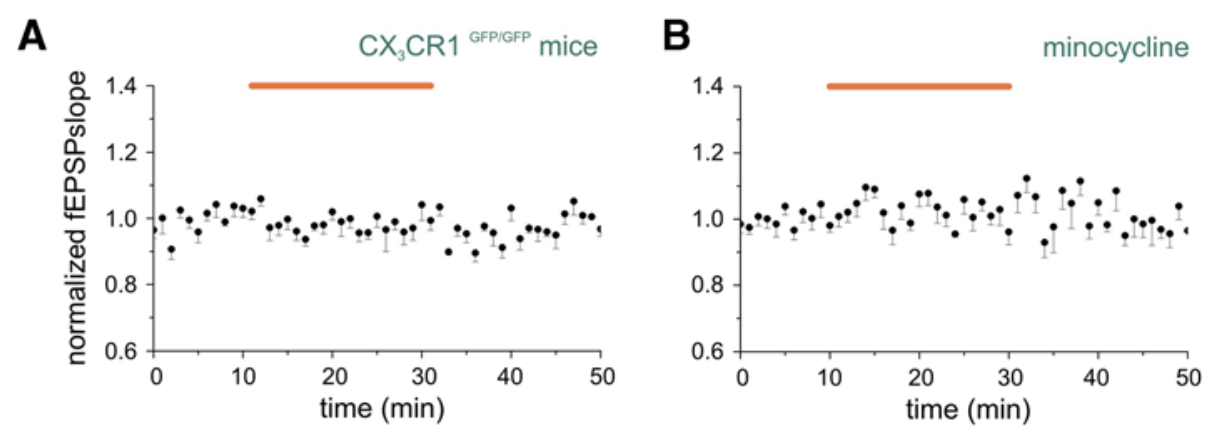

Figure $2 \mathrm{CX}_{3} \mathrm{CR} 1$ and microglia activation are required for $\mathrm{CX}_{3} \mathrm{CL} 1$ effects. Points represent mean $\pm \mathrm{SEM}$ of the $N$-methyl-D-aspartate receptor component of field excitatory postsynaptic potential (NMDA-fEPSP) slopes. Average timecourse of changes in NMDA-fEPSPs recorded in hippocampal slices. Horizontal bar, $C X_{3} C L 1$ application (5 nM). (A) $C X_{3} C L 1$-mediated effects required the presence of $C X_{3} C R 1$ ( $\left.n=7 / 3\right)$. (B) Microglia activation is necessary for $\mathrm{CX}_{3} \mathrm{CL} 1$ action. Slices pretreated for $1 \mathrm{~h}$ with minocycline (last 10 minutes in the graph) and then continuously superperfused. Cotreatment with $C X_{3} C L 1$ did not increase NMDA-fEPSPs ( $n=8 / 2$ ). 

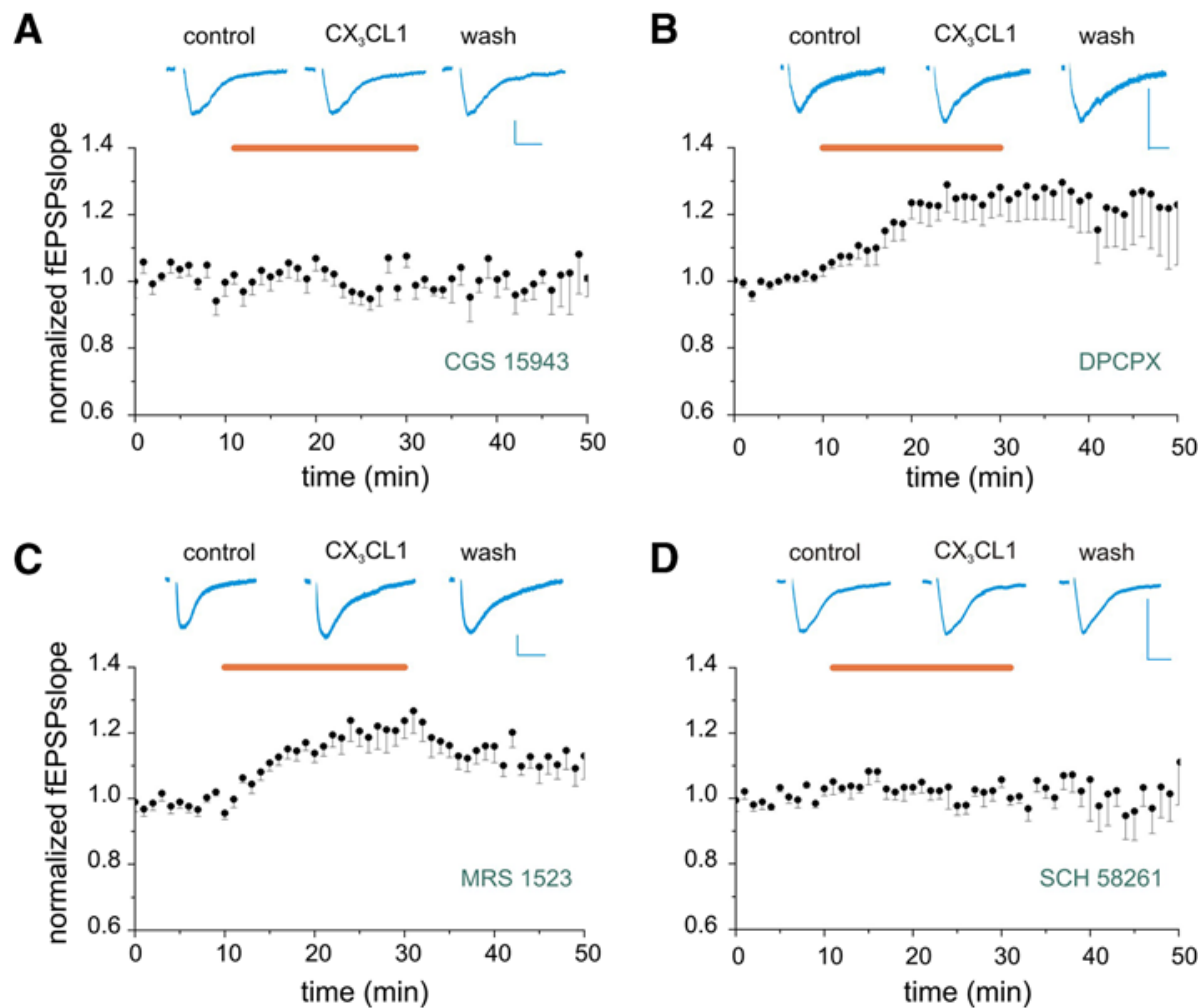

Figure 3 Adenosine receptors (ARs) are involved in $\mathrm{CX}_{3} \mathrm{CL}$ 1-mediated short-term potentiation (STP) of $\mathrm{N}$-methyl-D-aspartate receptor (NMDAR). (A-D) Slices pretreated for 20 minutes with AR antagonists (last 10 minutes in the graph) and then continuously treated. Inset on top: representative NMDAR component of field excitatory postsynaptic potential (NMDA-fEPSP) traces recorded in control condition, in the presence of $\mathrm{CX}_{3} \mathrm{CL} 1$ and during washout, as indicated (same time points as Figure 1). Vertical scale bar: $0.5 \mathrm{mV}$, horizontal scale bar: $20 \mathrm{~ms}$. Graphs represent the average timecourse of $\mathrm{CX}_{3} \mathrm{CL} 1$ effects on NMDA-fEPSPs in the presence of AR antagonists. Points: mean \pm SEM. Horizontal bar, $\mathrm{CX}_{3} \mathrm{CL} 1$ application (5 nM). (A) Slices superfusion with the non-selective AR antagonist, triazoloquinazoline (CGS15943) (25 nM) prevented CX ${ }_{3} \mathrm{CL} 1$ action $(n=9 / 4)$. (B) $C X_{3} C L 1$ application in the presence of 1,3-dipropyl-8-cyclopentylxanthine (DPCPX) $(25 n M)$, was effective $(n=9 / 5)$. (C) $C X_{3} C L 1$ application in the presence of 3-propyl-6-ethyl-5-[(ethylthio)carbonyl]-2 phenyl-4-propyl-3-pyridine carboxylate (MRS1523) (100 nM) induced a significant increase of NMDA-fEPSPs ( $\mathrm{n}=10 / 5)$. (D) 7-(2-phenylethyl)-5-amino-2-(2-furyl)-pyrazolo-[4,3-e]-1,2,4-triazolo[1,5-c]pyrimidine (SCH58261) $(10 \mathrm{nM})$ prevented $\mathrm{CX}_{3} \mathrm{CL} 1$ action $(n=6 / 3)$.

three mice). Similar results were obtained in $\mathrm{A}_{3} \mathrm{R}^{-/-}$mice, where $\mathrm{CX}_{3} \mathrm{CL} 1$ elicited a significant increase of NMDAfEPSPs slope (to $1.11 \pm 0.01, P<0.05$ vs baseline) that recovered upon withdrawal (to $1.02 \pm 0.01, P>0.05$ to baseline, Figure $4 \mathrm{~B}$, ten slices/two mice). Interestingly, in accordance with pharmacological data, in $\mathrm{A}_{2 \mathrm{~A}} \mathrm{R}$ deficient mice $\left(\mathrm{A}_{2 \mathrm{~A}} \mathrm{R}^{-/-}\right) \mathrm{CX} \mathrm{C}_{3} \mathrm{CL} 1$ was unable to affect NMDAfEPSPs. $(P>0.05$, vs baseline, 11 slices $/ 3$ mice, Figure $4 C$ ), thus pointing to an essential role of $\mathrm{A}_{2 \mathrm{~A}} \mathrm{R}$ activity in the $\mathrm{CX}_{3} \mathrm{CL} 1$ effect. To further support this observation, we tested whether a selective $\mathrm{A}_{2 \mathrm{~A}} \mathrm{R}$ agonist, VT7 (50 nM), was able to mimic $\mathrm{CX}_{3} \mathrm{CL} 1$ effect. The results in Figure $5 \mathrm{~A}$ demonstrate that in the presence of adenosine deaminase (ADA, $1 \mathrm{U} / \mathrm{ml})$, which removes ambient adenosine [50], VT7 induced an increase of NMDA-fEPSPs slope (to $1.18 \pm 0.01, P<0.05$ vs baseline, nine slices/two mice) that did not recover after washout (to $1.15 \pm 0.01$, $P<0.05$ vs baseline).
Considered together, our findings indicate that the influence of $\mathrm{CX}_{3} \mathrm{CL} 1$ on NMDARs is mediated by the $\mathrm{A}_{2 \mathrm{~A}} \mathrm{R}$ activity.

\section{D-serine is involved in $\mathrm{CX}_{3} \mathrm{CL}$ 1-dependent modulation of NMDARs}

Recent evidence indicates that D-serine serves as indispensable cofactor at the glycine binding site of NMDARs representing a new and important glia-derived neuromodulatory factor [51]. In fact, in glial cells, D-serine is synthesized and metabolized endogenously by the enzymes serine racemase (SR) [52] and D-amino acid oxidase (DAAO) [53], respectively.

To investigate whether $\mathrm{D}$-serine is involved in $\mathrm{CX}_{3}$ CL1-mediated modulation of NMDARs, we first treated the slices with the selective NMDAR glycine-site antagonist 5,7-dichlorokynurenic acid (DCKA) at a concentration $(750 \mathrm{nM})$ known to reduce NMDA responses 


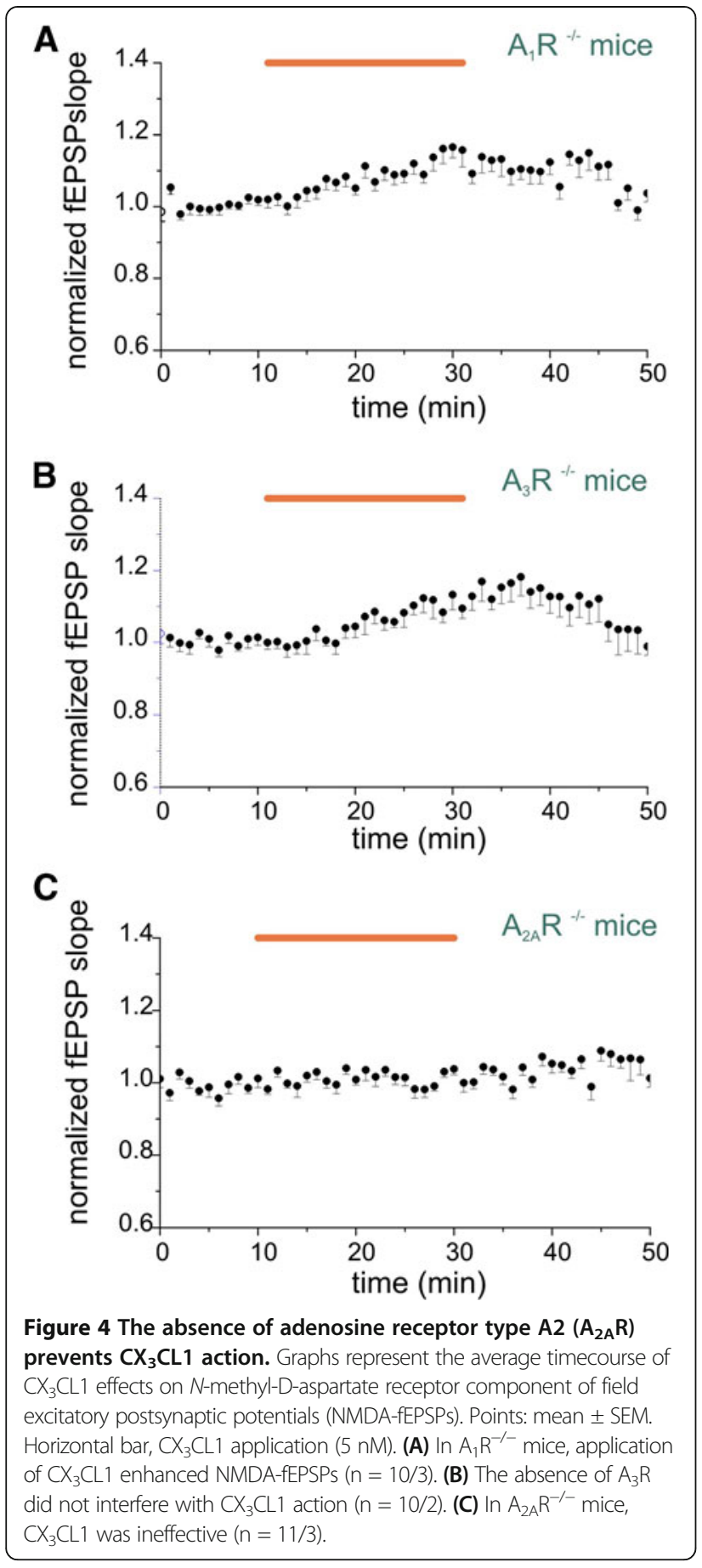

by around $25 \%$ [54] and able to prevent $\mathrm{D}$-serine mediated increase of NMDA-fEPSPs slope $(\mathrm{n}=7$, data not shown). At this concentration, DCKA abolished $\mathrm{CX}_{3} \mathrm{CL} 1$ effects on NMDA-fEPSPs $(P>0.05$ vs baseline, eight slices/four mice, Figure 6A).

To disclose a possible $\mathrm{D}$-serine versus glycine coagonist requirement, we treated the slices with DAAO $(0.1 \mathrm{U} / \mathrm{ml})$. Excess catalase $(300 \mathrm{U} / \mathrm{ml})$ was added in the solution in order to avoid the possibility of hydrogen peroxide
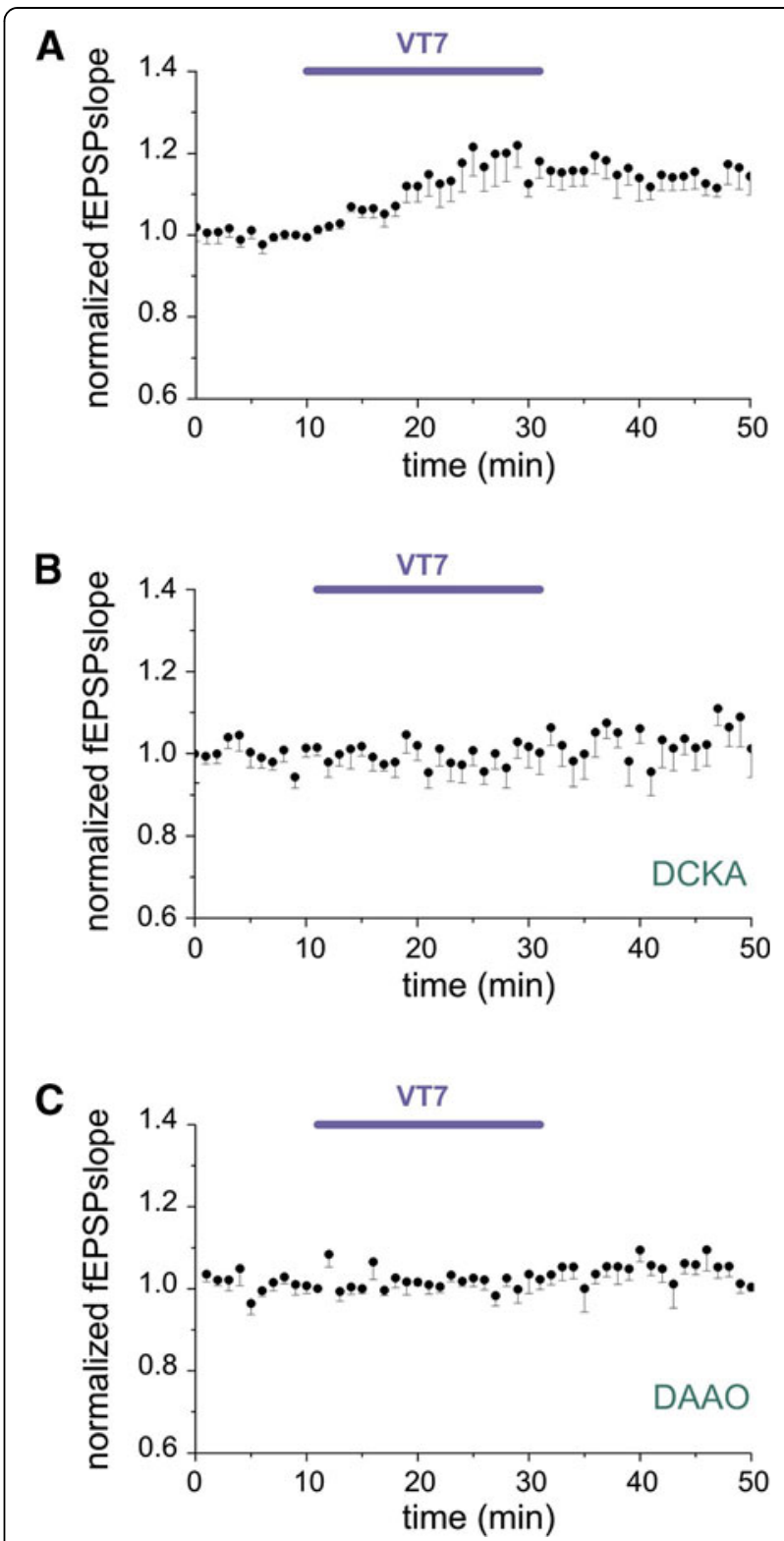

Figure 5 5-(6-Amino-2-(phenethylthio)-9H-purin-9-yl)- $\mathrm{N}$-ethyl-3, 4-dihydroxytetrahydrofuran-2-carboxamide (VT7) increases hippocampal $\mathrm{N}$-methyl-D-aspartate receptor component of field excitatory postsynaptic potentials (NMDA-fEPSPs) and its action depends on D-serine. Averaged timecourse of changes in NMDA-fEPSPs recorded in hippocampal slices. Points: mean \pm SEM. Horizontal bar, VI7 application (50 nM). Inset on top: representative NMDA-fEPSP traces recorded in control conditions, in the presence of VT7 and during washout, as indicated (same time points as Figure 1). Vertical scale bar: $0.1 \mathrm{mV}$, horizontal scale bar: $20 \mathrm{~ms}$. Slices treated with adenosine deaminase (ADA), $1 \mathrm{U} / \mathrm{ml}$. (A) Application of VT7 enhances NMDA-fEPSP slopes $(n=9 / 2)$. (B) Blocking of the NMDAR D-serine site completely prevents the VT7 effect on NMDA-fEPSP slopes. Slices pretreated with 5,7dicholorokynurenic acid (DCKA) (750 nM) for 20 minutes (last 10 minutes in the graph) before VT7 application and then continuously treated $(n=11 / 3)$. (C) Degradation of D-serine block VT7-mediated NMDA modulation. Slices pretreated for $1 \mathrm{~h}$ and then continuously superperfused with D-amino acid oxidase (DAAO) $(0.1 \mathrm{U} / \mathrm{ml})$ and catalase $(300 \mathrm{U} / \mathrm{ml})$. Cotreatment with VT7 did not increase NMDA-fEPSPs slope $(n=7 / 3)$. 


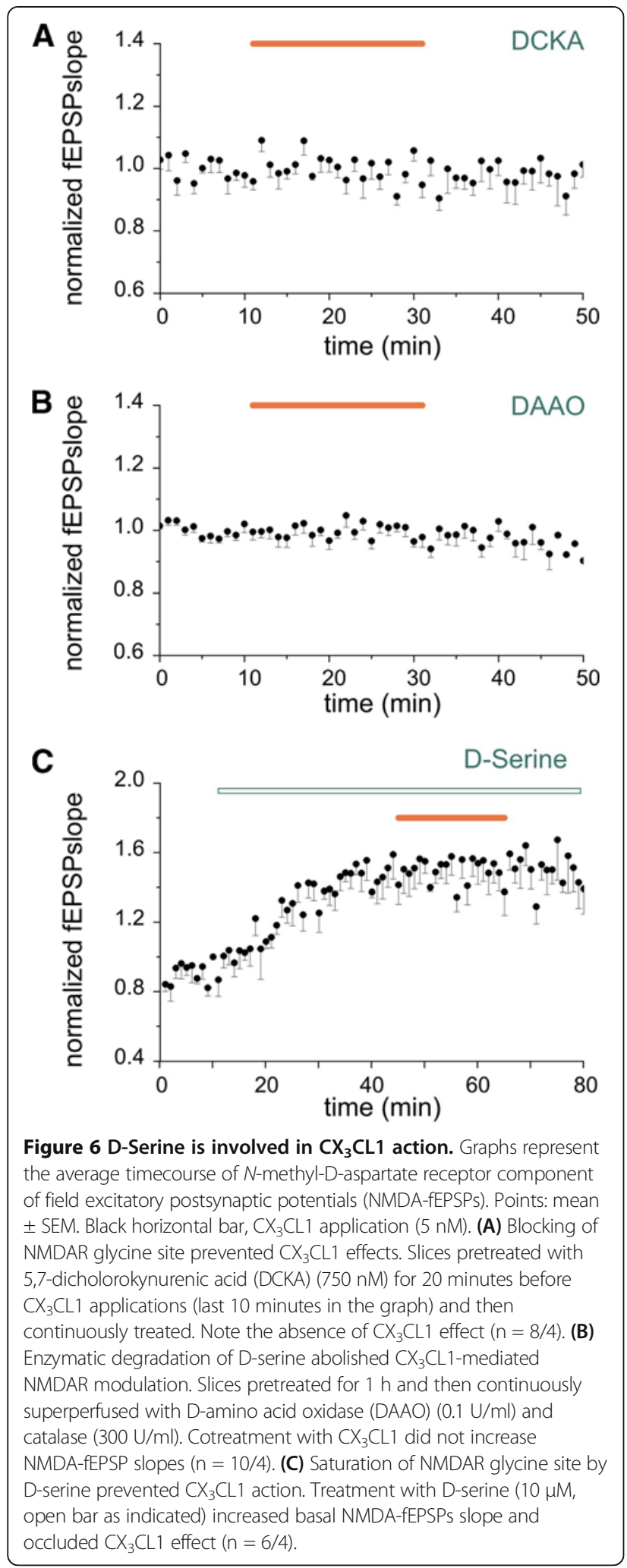

production from the enzymatic degradation of D-serine by DAAO. Under this condition, DAAO completely prevented $\mathrm{CX}_{3} \mathrm{CL} 1$ action $(P>0.05$ vs baseline, ten slices/ four mice, Figure $6 \mathrm{~B}$ ), indicating that $\mathrm{D}$-serine is necessary. To further confirm the involvement of $\mathrm{D}$-serine in the modulation of NMDARs by $\mathrm{CX}_{3} \mathrm{CL} 1$, we applied exogenous D-serine $(10 \mu \mathrm{M}$, six slices/four mice, Figure $6 \mathrm{C})$ to hippocampal slices. As shown in Figure 6C, D-serine produced an increase in NMDA-fEPSPs slope reaching a plateaux effect within 20 minutes (up to $64.4 \pm 0.01$ after 40 minutes treatment, $P<0.05$ vs baseline). Subsequent coapplication of $\mathrm{CX}_{3} \mathrm{CL} 1$ failed to further increase NMDA-fEPSPs slope ( $P>0.05$ vs D-serine alone), indicating that saturation of the glycine site by $\mathrm{D}$-serine interferes with chemokine action.

Since we have demonstrated that the $\mathrm{CX}_{3} \mathrm{CL1}$ effect is prevented by hampering both $\mathrm{D}$-serine and $\mathrm{A}_{2 \mathrm{~A}} \mathrm{R}$ functions, we investigated whether the two pathways share some common mechanisms of action. For this reason we applied the $A_{2 A} R$ agonist VT7 (in the presence of ADA, $1 \mathrm{U} / \mathrm{ml}$ ) while partially blocking the NMDAR D-serine site by DCKA. In this condition, VT7 failed to increase NMDAfEPSPs slope ( $P>0.05$ vs baseline, Figure 5B, 11 slices/ 3 mice). In addition, slices pretreatment with DAAO $(0.1 \mathrm{U} / \mathrm{ml}$, in the presence of catalase, $300 \mathrm{U} / \mathrm{ml}$, and ADA, $1 \mathrm{U} / \mathrm{ml}$ ) inhibits VT7 action ( $>0.05$ vs baseline, Figure $5 \mathrm{C}$, seven slices/three mice). Taken together this evidence suggests that NMDAR modulation mediated by $\mathrm{A}_{2 \mathrm{~A}} \mathrm{R}$ requires D-serine.

\section{$\mathrm{CX}_{3} \mathrm{CL} 1$ and VT7 stimulate the release of D-serine from glia cells}

To further investigate the possible source of D-serine in $\mathrm{CX}_{3} \mathrm{CL} 1$-induced NMDAR modulation, we measured $\mathrm{D}$-serine levels in glia-conditioned medium. The control medium (M-ACSF) did not contain D-serine, as it is shown in Additional file 2: Figure S2.

Primary cortical glial cells and isolated microglial cell populations were stimulated with $\mathrm{CX}_{3} \mathrm{CL} 1(10 \mathrm{nM})$ for different times (20 minutes, $2 \mathrm{~h}$ and 20 minutes or $4 \mathrm{~h}$ ). After stimulation, mass spectrometry was performed on media samples.

Treatment of both primary purified microglia and mixed glia with $\mathrm{CX}_{3} \mathrm{CL} 1$ resulted in a large increase in D-serine in the medium (Figure 7). In particular, in microglial cells $\mathrm{CX}_{3} \mathrm{CL} 1$ induced a significant increase in D-serine release at all the incubation times considered $(1.53 \pm 0.08$ after 20 minutes, $1.26 \pm 0.07$ after $2 \mathrm{~h}$ and 20 minutes and $2.63 \pm 0.80$ after $4 \mathrm{~h}, P<0.05$ in all cases vs untreated, $\mathrm{n}=8$, Figure 7A). Similarly, $\mathrm{CX}_{3} \mathrm{CL} 1$ treatment augmented $\mathrm{D}$-serine level in the medium of mixed glia $(1.76 \pm 0.19$ after 20 minutes, $1.66 \pm 0.11$ after $2 \mathrm{~h}$ and 20 minutes and $1.52 \pm 0.24$ after $4 \mathrm{~h}, P<0.05$ in all cases vs untreated, $\mathrm{n}=8$, Figure $7 \mathrm{~B}$ ).

We then tested whether also the $A_{2 A} R$ agonist VT7 was able to modulate the release of $\mathrm{D}$-serine from glia. For this purpose we stimulated the cells with VT7 $(50 \mathrm{nM})$ in the 

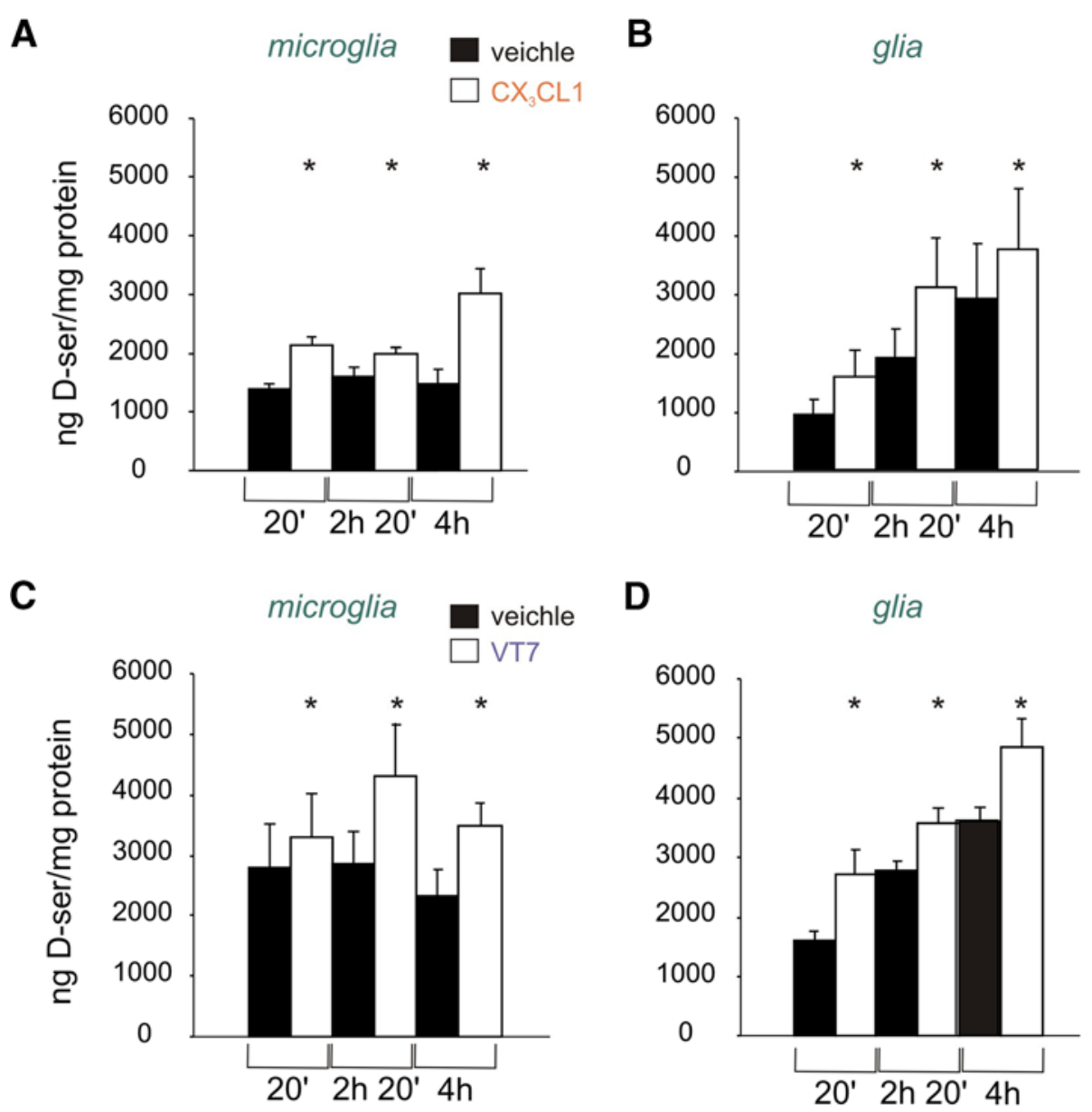

Figure $7 \mathrm{CX}_{3} \mathrm{CL} 1$ and 5-(6-amino-2-(phenethylthio)-9H-purin-9-yl)- $\mathrm{N}$-ethyl-3,4-dihydroxytetrahydrofuran-2-carboxamide (VT7) induce extracellular accumulation of D-serine. Mass spectroscopy analysis of D-serine levels in primary purified microglia or mixed glia culture medium (A,B). Cells were stimulated with $\mathrm{CX}_{3} \mathrm{CL} 1(10 \mathrm{nM})$ or vehicle and after 20 minutes, $2 \mathrm{~h}$ and 20 minutes or $4 \mathrm{~h}$ (as indicated) medium was collected and analyzed for D-serine content. Results are expressed as ng extracellular D-serine accumulated per mg of cellular proteins and are the mean \pm SEM of eight independent experiments. (A) Shows purified microglia, (B) shows mixed glia culture medium. (C,D) Cells stimulated with VT7 $(50 \mathrm{nM})$ plus adenosine deaminase (ADA, $1 \mathrm{U} / \mathrm{ml}$ ) or vehicle (ADA, $1 \mathrm{U} / \mathrm{ml}$ ) and samples collected as in (A,B). (C) Shows purified microglia, (D) shows mixed glia culture medium. Results are the mean \pm SEM of nine experiments (C) or 12 experiments (D). White square, vehicle; black square treatment, as indicated. ${ }^{*} \mathrm{P}<0.05$.

continuous presence of adenosine deaminase (ADA, $1 \mathrm{U} / \mathrm{ml})$. As for $\mathrm{CX}_{3} \mathrm{CL} 1$, the $\mathrm{A}_{2 \mathrm{~A}} \mathrm{R}$ agonist was able to induce an increment in the basal level of D-serine. Specifically, VT7 treatment produced an increase in D-serine release in both primary purified microglia (up to: $1.28 \pm 0.13$ after 20 minutes, $1.38 \pm 0.10$ after $2 \mathrm{~h}$ and 20 minutes and $1.60 \pm 0.30$ after $4 \mathrm{~h}, P<0.05$ in all cases vs untreated, $\mathrm{n}=9$, Figure $7 \mathrm{C}$ ) and mixed glia medium (up to: $1.53 \pm$ 0.10 after 20 minutes, $1.37 \pm 0.06$ after $2 \mathrm{~h}$ and 20 minutes and $1.47 \pm 0.12$ after $4 \mathrm{~h}, P<0.05$ in all cases vs untreated, $\mathrm{n}=12$, Figure 7D), respectively. Interestingly, the control basal level of D-serine in purified microglia medium was unchanged at different time points, whereas in mixed glia it accumulates upon time, and it had similar values (at 20 minutes, both in M-ACSF or M-ACSF plus ADA, $P>0.05$ for all cases). In addition, the level of basal D-serine released by mixed glia or microglia was in the order of $10 \mathrm{fmol} /$ cell, accordingly to previously reported values [25].

We further tested the ability of VT7 to induce the release of D-serine form neurons in the presence of ADA. During treatment, no variation in the basal level of D-serine was observed, at all time points considered $(P>0.05$ vs untreated, $n=12$ ). Notably, the basal level of D-serine released by neurons was much lower compared to glia (at 20 minutes: $37.24 \pm 7.02 \mathrm{ng} / \mathrm{mg}$ of protein, $\mathrm{n}=12$ ).

\section{Discussion}

The main finding of the present study is that NMDAR function, in CA1 hippocampal region, is potentiated by $\mathrm{CX}_{3} \mathrm{CL} 1$ application. The activation of the glial $\mathrm{A}_{2 \mathrm{~A}} \mathrm{R}$ and the release of the NMDAR coagonist $\mathrm{D}$-serine are likely major causative factors for the observed NMDA 
potentiation. Interestingly this effect is postsynaptic in nature, depends on microglia and requires the presence of $\mathrm{CX}_{3} \mathrm{CR} 1$. Specifically, the parameter related to changes in the probability of vesicular release at the synapse, such as PPR, was not affected by $\mathrm{CX}_{3} \mathrm{CL} 1$, indicating that the chemokine did not potentiate NMDA-fEPSPs by altering presynaptic glutamate release (see also $[15,44])$. In addition, the use of genetically modified mice lacking $\mathrm{CX}_{3} \mathrm{CR} 1$ or inhibiting microglia function by minocycline treatment prevented $\mathrm{CX}_{3} \mathrm{CL}$ 1-mediated potentiation of NMDAR function.

\section{$A_{2 A} R$ activity is involved in $C_{3} C L 1$ effect}

It is established that adenosine acts as neuromodulator of NMDAR function; in particular $\mathrm{A}_{2 \mathrm{~A}}$ Rs exert a facilitatory role on NMDARs $[55,56]$. Nevertheless, the consequences of $\mathrm{A}_{2 \mathrm{~A}} \mathrm{R}$ activation on synaptic transmission in physiological conditions of adenosine release remained elusive. Since the ambient level of adenosine is sufficient to activate inhibitory $A_{1} R$ but not facilitatory $A_{2 A} R$, possibly due to differences in affinity [57], it is believed that specific stimulation such as high-frequency bursts is needed to increase the level of adenosine to values able to activate $A_{2 A} R$ [58]. Indeed, we have previously demonstrated that stimulation of microglial cells by $\mathrm{CX}_{3} \mathrm{CL1}$ induces an increase in extracellular level of adenosine [12].

Here, we reported that $\mathrm{CX}_{3}$ CL1-mediated activation of $\mathrm{A}_{2 \mathrm{~A}} \mathrm{R}$ influences the NMDA-mediated component of excitatory synaptic transmission. In particular, the specific $\mathrm{A}_{2 \mathrm{~A}} \mathrm{R}$ blocker SCH58261, as well as the genetic ablation of $A_{2 A} R$, prevented the short-term potentiation of NMDA fEPSPs induced by $\mathrm{CX}_{3} \mathrm{CL} 1$. In addition, the specific $\mathrm{A}_{2 \mathrm{~A}} \mathrm{R}$ agonist VT7 was able to mimic $\mathrm{CX}_{3} \mathrm{CL} 1$ effect, producing a similar potentiation of NMDA-fEPSPs.

\section{D-serine is essential for $\mathrm{CX}_{3} \mathrm{CL} 1$-mediated potentiation of NMDA-fEPSPs}

It is well established that D-serine act as an essential coagonist of NMDAR. The production of D-serine in the mammalian brain results from the activity of SR, an enzyme that converts L-serine into D-serine [59]. Astrocytes synthesize and release D-serine [25], for instance following activation of AMPARs by glutamate released from nerve terminals $[24,60]$. In contrast, scarce information is available on microglia derived D-serine. It has been reported that microglia express serine racemase [27-29] and release $D$-serine after activation with amyloid $\beta$-peptide [25].

We demonstrated that $\mathrm{D}$-serine is involved in $\mathrm{CX}_{3} \mathrm{CL1}$ mediated potentiation of NMDA-fEPSPs because its action is prevented by: (i) the selective NMDAR antagonist of the glycine (and D-serine)-binding site DCKA, (ii) the enzymatic degradation of D-serine by DAAO, and (iii) the saturation of the coagonist site by $\mathrm{D}$-serine.
In addition, mass spectrometry analysis revealed that treatment of primary mixed glial cells and purified microglial population with $\mathrm{CX}_{3} \mathrm{CL} 1$ induces a significant increase of D-serine release in the extracellular medium. The glial population used for these studies was derived from cerebral cortices and we are aware that microglial phenotypes differ across brain regions and ages $[61,62]$, so that results from these preparation cannot be directly transferred to hippocampal glial cells; nevertheless these data strongly support a direct role of $\mathrm{CX}_{3} \mathrm{CL} 1$ in controlling D-serine release from glia, that need further investigation, and clearly demonstrate a basal release of D-serine from microglial cells that can be further increased by $\mathrm{CX}_{3} \mathrm{CL} 1$ treatment.

Overall, the evidence suggests that both $\mathrm{A}_{2 \mathrm{~A}} \mathrm{R}$ activity and D-serine release are needed for $\mathrm{CX}_{3} \mathrm{CL} 1$-mediated potentiation of NMDA-fEPSPs. Are these factors interacting in some way? Our results point to a possible crosstalk between $\mathrm{A}_{2 \mathrm{~A}} \mathrm{R}$ activity and D-serine release. First of all, at Schaffer collateral-CA1 synapses the $\mathrm{A}_{2 \mathrm{~A}} \mathrm{R}$ agonist failed to increase NMDA-fEPSPs when the NMDA glycine site was partially blocked by DCKA, indicating an extracellular modulation (via $\mathrm{D}$-serine binding) of NMDAR mediated by the activation of $\mathrm{A}_{2 \mathrm{~A}} \mathrm{R}$. It is unlikely that the partial block of the NMDAR extracellular site could mask a possible $A_{2 \mathrm{~A}} \mathrm{R}$ mediated intracellular modulation of the receptor [63], the latter actually occurring at hippocampal mossy-CA3 synapse via calcium amplification signals [56]. In addition, enzymatic degradation of D-serine by DAAO prevented the $\mathrm{A}_{2 \mathrm{~A}} \mathrm{R}$ agonist mediated potentiation of NMDA-fEPSPs, supporting the D-serine requirement for VT7 effect.

Secondly, by means of mass spectrometry analysis, we have shown that primary glial cells and purified microglia are capable to release D-serine in the medium after stimulation with VT7. These observations suggest a direct role of $\mathrm{A}_{2 \mathrm{~A}} \mathrm{R}$ in controlling the release of $\mathrm{D}$-serine from glia that in turn can modulate NMDAR functions. To the best of our knowledge, this is the first report on adenosine-mediated release of D-serine from glia. $\mathrm{A}_{2 \mathrm{~A}} \mathrm{R}$ are indeed expressed on microglia and astrocytes $[49,64,65]$, usually coupled to $G_{s}$ proteins, enhancing PKA or PKC activity $[56,58,66]$. Interestingly, PKC activity seems relevant in regulating SR activity and D-serine availability [67-69]. Since it has been reported that neuronal cells can release D-serine, with controversial functions on synaptic NMDAR [70,71], we investigated whether VT7 stimulated D-serine release from neurons. The basal release of $\mathrm{D}$-serine from neurons appeared markedly reduced compared to glia and the activation of neuronal $A_{2 A} R$ was unable to further increase the extracellular D-serine levels, although we cannot exclude an indirect modulation of neuronal D-serine via other mediators released by $\mathrm{CX}_{3} \mathrm{CL} 1$-activated microglia.

We have previously demonstrated that $\mathrm{CX}_{3} \mathrm{CL} 1$ inhibits AMPA-mediated transmission and LTP expression $[15,17]$ while here we reported that $\mathrm{CX}_{3} \mathrm{CL} 1$ potentiates NMDAR. 
We speculate that the persistent $\mathrm{CX}_{3}$ CL1-mediated potentiation of NMDA function and the consequent calcium increase could interfere with the complex mechanisms of LTP induction that depends not only by the precise amplitude but also by the duration of postsynaptic $\mathrm{Ca}^{2+}$ increase and by the recent history of synaptic activity. Indeed, it has been demonstrated that prior activation of NMDAR either by synaptic or pharmacological stimulation could effectively inhibit the subsequent LTP induction [72,73].

Since in our experimental setting we recorded synaptic NMDAR blocking AMPAR component, it would be informative to investigate $\mathrm{CX}_{3}$ CL1-mediated NMDAR modulation in a more physiological condition, where neuronal and glial AMPAR are activable.

Interestingly, the effect of $\mathrm{CX}_{3} \mathrm{CL} 1$ seems to be specific for the synaptic NMDARs that are exclusively gated by the coagonist D-serine [23]. It has been reported that activation of synaptic NMDARs (NR2A-containing NMDARs) preferentially triggers cell survival pathways, whereas stimulation of the whole-cell population of NMDARs and/ or selective activation of extrasynaptic NMDARs (NR2Bcontaining NMDARs) signals toxic stimuli $([74,75]$, but see also [23]). Therefore, $\mathrm{CX}_{3}$ CL1-mediated potentiation of synaptic NMDAR function can possibly contribute to the neuroprotective action of $\mathrm{CX}_{3} \mathrm{CL} 1$ described in different in vitro and in vivo conditions [11,12,14].

Future studies are warranted to discern the role and the precise mechanism of $\mathrm{CX}_{3} \mathrm{CL} 1$-mediated potentiation of NMDA-fEPSPs in both physiological and pathological condition, with particular attention to the sequence of mediators and cell types involved, namely neurons, astrocytes or microglia. Nevertheless, considering overall data, we can speculate that on microglial cells the activation of $\mathrm{CX}_{3} \mathrm{CR} 1$ triggers the release of adenosine that in turn, via $\mathrm{A}_{2 \mathrm{~A}} \mathrm{R}$ activity, increases the release of $\mathrm{D}$-serine from glia leading to a potentiation of NMDA function (Figure 8).

\section{Conclusions}

In summary, we have demonstrated a direct association between the effects of $\mathrm{CX}_{3} \mathrm{CL} 1$ on NMDAR activation and increased levels of $\mathrm{D}$-serine and $\mathrm{A}_{2 \mathrm{~A}} \mathrm{R}$ activity within the CA1 region of the hippocampus. The $\mathrm{CX}_{3} \mathrm{CL} 1-\mathrm{CX}_{3} \mathrm{CR} 1$ axis therefore represents a pathway for direct communication between neural cells and microglia.

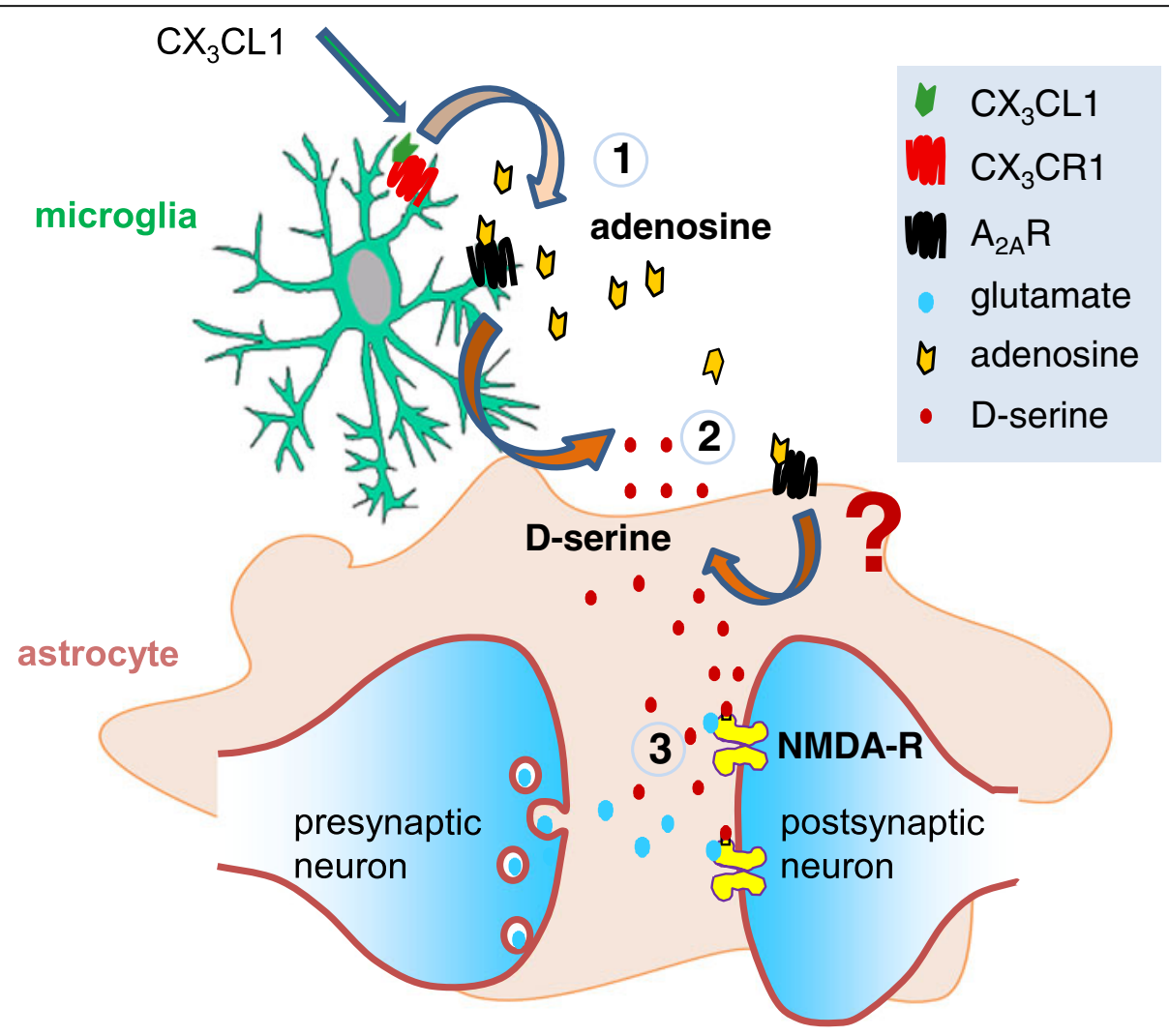

Figure 8 Suggested mechanism of $\mathrm{CX}_{3} \mathrm{CL} 1$ action. Activation of microglial $\mathrm{CX}_{3} \mathrm{CR} 1$ by exogenous application of $\mathrm{CX}_{3} \mathrm{CL} 1$ induces the release of adenosine (1) that in turn activates adenosine receptor type $A 2\left(A_{2 A} R\right)$ located on microglia cells and, possibly, on astrocytes stimulating the release of D-serine (2). The binding of the cofactor D-serine to the synaptically activated N-methyl-D-aspartate receptors (NMDARs) (3) potentiates the receptor function. Note that a-amino-3-hydroxy-5-methyl-4-isoxazolepropionic acid receptors (AMPARs) are blocked and, for clarity, only factors demonstrated to play a role in the described mechanism are represented. 


\section{Additional files}

Additional file 1: Figure S1. Extracted ion chromatogram detected at $\mathrm{m} / \mathrm{z}$ 356.1/192.0 (Q1/Q3) which is specific for the Marfey's derivatives L-Ser (2,4-dinitro-phenyl-5-L-alanine amide- (DNPA-)L-Ser) and D-Ser (DNPA-D-Ser). Note the clear resolution of Marfey's derivative, DNPA-L-Ser and DNPA-D-Ser

Additional file 2: Figure S2. Extracted ion chromatogram of a blank sample. Note the absence of peaks in modified artificial cerebrospinal fluid (M-ACSF) that interfere with 2,4-dinitro-phenyl-5-L-alanine amide- (DNPA-)LSer or DNPA-D-Ser.

Additional file 3: Figure S3. $\mathrm{CX}_{3} \mathrm{CL} 1$ does not affect afferent volley and paired pulse facilitation (PPF). (A) Representative traces of NMDA-fEPSPs responses in control, after 20 minutes of $\mathrm{CX}_{3} \mathrm{CL} 1$ and after 20 minutes of wash. Note the potentiation of the NMDA-fEPSPs during chemokine treatment without changes in the amplitude of the afferent volley. (B) Top: representative traces of $\mathrm{N}$-methyl-D-aspartate receptor component of field excitatory postsynaptic potentials (NMDA-fEPSPs) responses evoked by a pair of stimuli (50 ms interval) delivered to the Shaffer collateral in control and after 20 minutes of $\mathrm{CX}_{3} \mathrm{CL} 1$ application, as indicated (vertical scale bar: $0.2 \mathrm{mV}$, horizontal scale bar: $20 \mathrm{~ms}$ ). Bottom: histogram of paired-pulse ratio (PPR), expressed as the ratio of the amplitude of the second fEPSP vs the first $(n=6 / 4)$. (C) Top: representative traces of NMDA currents evoked by a pair of stimuli as in (B); (cells held at $10 \mathrm{mV}$ in standard artificial cerebrospinal fluid (ACSF), vertical scale bar: 20 pA, horizontal scale bar: 20 ms). Bottom: histogram of paired-pulse ratio (PPR) expressed as the ratio of the peak amplitude of the second response vs the first $(n=5 / 5)$. Note no difference in PPR before and after $\mathrm{CX}_{3} \mathrm{CL} 1$ application. Bars: mean $\pm \mathrm{SEM}, \mathrm{CX}_{3} \mathrm{CL} 1$ (5 nM).

\section{Competing interests}

The authors declare they have no competing interests.

\section{Authors' contributions}

LM, MS and CL conceived and designed the experiments; MS and LM performed and analyzed electrophysiological experiments, MADC participated to patch-clamp experiments; MS and GCh performed stimulation experiments with cultures; LA performed mass spectrometry analysis. $\mathrm{GCr}$ provided VT7; LM and $\mathrm{CL}$ wrote the paper. All authors have read and approved the final version of the manuscript.

\section{Acknowledgments}

This work was supported by research funding from: Istituto Pasteur, Fondazione Cenci Bolognetti to CL and PRIN 2009 to CL; MS was supported by the PhD program in Neurophysiology, Sapienza University, Rome. We thank Dr Cristina Marchetti and Dr Davide Ragozzino for critical reading, Dr Bertil B Fredholm for providing us KO mice and critical reading, Francesca Filipponi for helping in mass spectrometry analysis, and Dr Clotilde Lauro and Dr Teresa Ciotti for culture advice.

\section{Author details}

${ }^{1}$ Institute Pasteur-Cenci Bolognetti Foundation, Department of Physiology and Pharmacology, University Sapienza, Rome, Italy. ${ }^{2}$ School of Pharmacy, Medicinal Chemistry Unit, University of Camerino, Camerino, Italy. ${ }^{3}$ IRCCS Neuromed, Pozzilli, Italy.

Received: 7 January 2013 Accepted: 28 May 2013

Published: 27 August 2013

\section{References}

1. Rostène W, Kitabgi P, Parsadaniantz SM: Chemokines: a new class of neuromodulator. Nat Rev Neurosci 2007, 8:895-903.

2. Réaux Le Goazigo A, Van Steenwinckel J, Rostène W, Mélik Parsadaniantz S: Current status of chemokines in the adult CNS. Prog Neurobiol 2013, 104:67-92.

3. Harrison LK, Jiang Y, Chen S, Xia Y, Maciejewski D, McNamara RK, Streit JW, Salafranca MN, Adhikari S, Thompson DA, Botti P, Bacon KB, Feng L: Role for neuronally derived fractalkine in mediating interactions between neurons and CX3CR1-expressing microglia. Proc Natl Acad Sci USA 1998, 95:10896-10901.
4. Hatori K, Nagai A, Heisel R, Ryu JK, Kim SU: Fractalkine and fractalkine receptors in human neurons and glial cells. J Neurosci Res 2002, 69:418-426.

5. Cardona AE, Pioro EP, Sasse ME, Kostenko V, Cardona SM, Dijkstra IM, Huang D, Kidd G, Dombrowski S, Dutta R, Lee JC, Cook DN, Jung S, Lira SA, Littman DR, Ransohoff RM: Control of microglial neurotoxicity by the fractalkine receptor. Nat Neurosci 2006, 9:917-924.

6. Jung S, Aliberti J, Graemmel P, Sunshine MJ, Kreutzberg GW, Sher A, Littman DR: Analysis of fractalkine receptor CX(3)CR1 function by targeted deletion and green fluorescent protein reporter gene insertion. Mol Cell Biol 2000, 20:4106-4114.

7. Wolf Y, Yona S, Kim KW, Jung S: Microglia, seen from the CX3CR1 angle. Front Cell Neurosci 2013, 7:26.

8. Hughes PM, Botham MS, Frentzel S, Mir A, Perry VH: Expression of fractalkine (CX3CL1) and its receptor, $C X 3 C R 1$, during acute and chronic inflammation in the rodent CNS. Glia 2002, 37:314-327.

9. Sunnemark D, Eltayeb S, Nilsson M, Wallström E, Lassmann H, Olsson T: CX3CL1 (fractalkine) and CX3CR1 expression in myelin oligodendrocyte glycoprotein-induced experimental autoimmune encephalomyelitis: kinetics and cellular origin. J Neuroinflammation 2005, 2:17-31.

10. D'Haese JG, Friess H, Ceyhan GO: Therapeutic potential of the chemokine-receptor duo fractalkine/CX3CR1: an update. Expert Opin Ther Targets 2012, 16:613-618.

11. Limatola C, Lauro C, Catalano M, Ciotti MT, Bertollini C, Di Angelantonio S, Ragozzino D, Eusebi F: Chemokine CX3CL1 protects rat hippocampal neurons against glutamate-mediated excitotoxicity. J Neuroimmunol 2005, 166:19-28.

12. Lauro C, Di Angelantonio S, Cipriani R, Sobrero F, Antonilli L, Brusadin V, Ragozzino D, Limatola C: Activity of adenosine receptors type 1 is required for CX3CL1-mediated neuroprotection and neuromodulation in hippocampal neurons. J Immunol 2008, 180:7590-7596.

13. Lauro C, Cipriani R, Catalano M, Trettel F, Chece G, Brusadin V, Antonilli L, van Rooijen N, Eusebi F, Fredholm BB, Limatola C: Adenosine A1 receptors and microglial cells mediate CX3CL1-induced protection of hippocampal neurons against Glu-induced death. Neuropsychopharmacology 2010, 35:1550-1559.

14. Cipriani R, Villa P, Chece G, Lauro C, Paladini A, Micotti E, Perego C, De Simoni MG, Fredholm BB, Eusebi F, Limatola C: CX3CL1 is neuroprotective in permanent focal cerebral ischemia in rodents. J Neurosci 2011, 31:16327-16335.

15. Ragozzino D, Di Angelantonio S, Trettel F, Bertollini C, Maggi L, Gross C, Charo IF, Limatola C, Eusebi F: Chemokine fractalkine/CX ${ }_{3} \mathrm{CL} 1$ negatively modulates active glutamatergic synapses in rat hippocampal neurons. J Neurosci 2006, 26:10488-10498.

16. Bertollini C, Ragozzino D, Gross C, Limatola C, Eusebi F: Fractalkine/CX3CL1 depresses central synaptic transmission in mouse hippocampal slices. Neuropharmacology 2006, 51:816-821

17. Maggi L, Trettel F, Scianni M, Bertollini C, Eusebi F, Fredholm BB, Limatola C: LTP impairment by fractalkine/CX(3)CL1 in mouse hippocampus is mediated through the activity of adenosine receptor type $3(A(3) R)$. J Neuroimmunol 2009, 215:36-42.

18. MacDermott AB, Mayer ML, Westbrook GL, Smith SJ, Barker IL: NMDA-receptor activation increases cytoplasmic calcium concentration in cultured spinal cord neurones. Nature 1986, 321:519-522.

19. Cull-Candy S, Brickley S, Farrant M: NMDA receptor subunits: diversity, development and disease. Curr Opin Neurobiol 2001, 11:327-335.

20. Hollmann M, Heinemann S: Cloned glutamate receptors. Annu Rev Neurosci 1994, 17:31-108.

21. Johnson JW, Ascher P: Glycine potentiates the NMDA response in cultured mouse brain neurons. Nature 1987, 325:529-531.

22. Matsui T, Sekiguchi M, Hashimoto A, Tomita U, Nishikawa T, Wada K: Functional comparison of D-serine and glycine in rodents: the effect on cloned NMDA receptors and the extracellular concentration. I Neurochem 1995, 65:454-458.

23. Papouin T, Ladépêche L, Ruel J, Sacchi S, Labasque M, Hanini M, Groc L, Pollegioni L, Mothet JP, Oliet SH: Synaptic and extrasynaptic NMDA receptors are gated by different endogenous coagonists. Cell 2012, 150:633-646.

24. Schell MJ, Brady RO Jr, Molliver ME, Snyder SH: D-serine as a neuromodulator: regional and developmental localization in rat brain glia resemble NMDA receptors. J Neurosci 1997, 17:1604-1615.

25. Wu SZ, Bodles AM, Porter MM, Griffin WS, Basile AS, Barger SW: Induction of serine racemase expression and $\mathrm{D}$-serine release from microglia by amyloid beta-peptide. J Neuroinflammation 2004, 1:2. 
26. Williams SM, Diaz CM, Macnab LT, Sullivan RK, Pow DV: Immunocytochemical analysis of D-serine distribution in the mammalian brain reveals novel anatomical compartmentalizations in glia and neurons. Glia 2006, 53:401-411.

27. Sasabe J, Chiba T, Yamada M, Okamoto K, Nishimoto I, Matsuoka M, Aiso S: $D$-serine is a key determinant of glutamate toxicity in amyotrophic lateral sclerosis. EMBO J 2007, 26:4149-5159.

28. Wang W, Barger SW: Cross-linking of serine racemase dimer by reactive oxygen species and reactive nitrogen species. J Neurosci Res 2012, 90:1218-1229

29. Hayashi $Y$, Ishibashi $H$, Hashimoto $K$, Nakanishi H: Potentiation of the NMDA receptor-mediated responses through the activation of the glycine site by microglia secreting soluble factors. Glia 2006, 53:660-668.

30. Block ML, Zecca L, Hong JS: Microglia-mediated neurotoxicity: uncovering the molecular mechanisms. Nat Rev Neurosci 2007, 8:57-69.

31. Flavin MP, Zhao G, Ho LT: Microglial tissue plasminogen activator (tPA) triggers neuronal apoptosis in vitro. Glia 2000, 29:347-354

32. Jarvis CR, Xiong ZG, Plant JR, Churchill D, Lu WY, MacVicar BA, MacDonald JF: Neurotrophin modilation of NMDA receptors in cultures murine and isolated rat neurons. J Neurophysiol 1997, 78:2363-2371.

33. Nakanishi H: Microglial functions and proteases. Mol Neurobio/ 2003, 27:163-176.

34. Yang S, Liu ZW, Qiao HF, Zhou WX, Zhang YX: Interleukin-1 b enhances NMDA receptor-mediated current but inhibits excitatory transmission. Brain Res 2005, 1034:172-179.

35. Deiva K, Geeraerts T, Salim H, Leclerc P, Héry C, Hugel B, Freyssinet JM, Tardieu M: Fractalkine reduces $\mathrm{N}$-methyl-D-aspartate-induced calcium flux and apoptosis in human neurons through extracellular signal-regulated kinase activation. Eur J Neurosci 2004, 20:3222-3232.

36. Cook DN, Cook DN, Chen SC, Sullivan LM, Manfra DJ, Wiekowski MT, Prosser DM, Vassileva G, Lira SA: Generation and analysis of mice lacking the chemokine fractalkine. Mol Cell Biol 2001, 21:3159-3165.

37. Johansson B, Halldner L, Dunwiddie TV, Masino SA, Poelchen W, Gimenez-Llort L, Escorihuela RM, Fernandez-Teruel A, Wiesenfeld-Hallin Z, Xu XJ, Hardemark A Betsholtz C, Herlenius E, Fredholm BB: Hyperalgesia, anxiety, and decreased hypoxic neuroprotection in mice lacking the adenosine $\mathrm{A} 1$ receptor. Proc Natl Acad Sci USA 2001, 98:9407-9412.

38. Salvatore CA, Tilley SL, Latour AM, Fletcher DS, Koller BH, Jacobson MA Disruption of the $A(3)$ adenosine receptor gene in mice and its effect on stimulated inflammatory cells. J Biol Chem 2000, 275:4429-4434.

39. Chen JF, Huang Z, Ma J, Zhu J, Moratalla R, Standaert D, Moskowitz MA, Fink JS, Schwarzschild MA: A(2A) adenosine receptor deficiency attenuates brain injury induced by transient focal ischemia in mice. J Neurosci 1999, 19:9192-9200.

40. Berna MJ, Ackermann BL: Quantification of serine enantiomers in rat brain microdialysate using Marfey's reagent and LC/MS/MS. J Chromatogr 2007, 846:359-363.

41. Neagu B, Strominger NL, Carpenter DO: Contribution of NMDA receptor-mediated component to the EPSP in mouse Schaffer collateral synapses under single pulse stimulation protocol. Brain Res 2008, 1240:54-61.

42. Zucker RS: Short-term synaptic plasticity. Ann Rev Neurosci 1989, 12:13-31.

43. Maggi L, Sola E, Minneci F, Le Magueresse C, Changeux JP, Cherubini E: Persistent decrease in synaptic efficacy induced by nicotine at Schaffer collateral-CA1 synapses in the immature rat hippocampus. J Physiol 2004, 559:863-874.

44. Maggi L, Scianni M, Branchi I, D'Andrea I, Lauro C, Limatola C: CX(3)CR1 deficiency alters hippocampal-dependent plasticity phenomena blunting the effects of enriched environment. Front Cell Neurosci 2011, 5:22.

45. Suzuki $H$, Sugimura $Y$, Iwama S, Suzuki $H$, Nobuaki O, Nagasaki $H$ : Minocycline prevents osmotic demyelination syndrome by inhibiting the activation of microglia. J Am Soc Nephrol 2010, 21:2090-2098.

46. Yrjanheikki J, Keinanen R, Pellikka M, Hokfelt T, Koistinaho J: Tetracyclines inhibit microglial activation and are neuroprotective in global brain ischemia. Proc Natl Acad Sci USA 1998, 95:15769.

47. Tikka TM, Koistinaho JE: Minocycline provides neuroprotection against $\mathrm{N}$-methyl-D-aspartate neurotoxicity by inhibiting microglia. J Immunol 2001, 166:7527-7533

48. Piccinin S, Di Angelantonio S, Piccioni A, Volpini R, Cristalli G, Fredholm BB, Limatola C, Eusebi F, Ragozzino D: CX3CL1-induced modulation at CA1 synapses reveals multiple mechanisms of EPSC modulation involving adenosine receptor subtypes. J Neuroimmunol 2010, 224:85-92.

49. Sebastião AM, Ribeiro JA: Tuning and fine-tuning of synapses with adenosine. Curr Neuropharmacol 2009, 7:180-194.
50. Lopes LV, Cunha RA, Kull B, Fredholm BB, Ribeiro JA: Adenosine $A_{2 A}$ receptor facilitation of hippocampal synaptic transmission is dependent on tonic $A_{1}$ receptor inhibition. Neuroscience 2002, 112:319-329.

51. Miller RF: D-serine as a glial modulator of nerve cells. Glia 2004, 47:275-283.

52. Wolosker H, Blackshaw S, Snyder SH: Serine racemase: a glial enzyme synthesizing D-serine to regulate glutamate- $N$-methyl-D-aspartate neurotransmission. Proc Natl Acad Sci USA 1999, 96:13409-13414.

53. Molla G, Sacchi S, Bernasconi M, Pilone MS, Fukui K, Polegioni L: Characterization of human D-amino acid oxidase. FEBS Lett 2006, 580:2358-2364.

54. Henneberger C, Papouin T, Oliet SH, Rusakov DA: Long-term potentiation depends on release of D-serine from astrocytes. Nature 2010, 463:232-236.

55. Tebano MT, Martire M, Rebola N, Pepponi R, Domenici MR, Gro MC, Schwarzschild MA, Chen JF, Cunha RA, Popoli P: Adenosine A2A receptors and mGluR5 are co-localized and functionally interact in the hippocampus: a possible key mechanism in the modulation of $\mathrm{N}$-methyl-D-aspartate effects. J Neurochem 2005, 95:1188-1200.

56. Rebola N, Lujan R, Cunha RA, Mulle C: Long-term potentiation of NMDA-EPSCs at hippocampal mossy fiber synapses: an essential role for adenosine A2A receptors. Neuron 2008, 57:121-134

57. Ciruela F, Casado V, Rodrigues RJ, Lujan R, Burgueno J, Canals M, Borycz J, Rebola N, Goldberg SR, Mallol J: Presynaptic control of striatal glutamatergic neurotransmission by adenosine $\mathrm{A} 1-\mathrm{A} 2 \mathrm{~A}$ receptor heteromers. J Neurosci 2006, 26:2080-2087.

58. Cunha RA: Adenosine as a neuromodulator and as a homeostatic regulator in the nervous system: different roles, different sources and different receptors. Neurochem Int 2001, 38:107-125.

59. Mustafa AK, Kim PM, Snyder SH: D-serine as a putative glial neurotransmitter. Neuron Glia Biol 2004, 1:275-281.

60. Mothet JP, Pollegioni L, Ouanounou G, Martineau M, Fossier P, Baux G: Glutamate receptor activation triggers a calcium-dependent and SNARE protein-dependent release of the gliotransmitter D-serine. Proc Natl Acad Sci USA 2005, 102:5606-5611

61. Lawson LJ, Perry VH, Dri P, Gordon S: Heterogeneity in the distribution and morphology of microglia in the normal adult mouse brain. Neuroscience 1990, 39:151-170.

62. Njie EG, Boelen E, Stassen FR, Steinbusch HW, Borchelt DR, Streit WJ: Ex vivo cultures of microglia from young and aged rodent brain reveal age-related changes in microglial function. Neurobiol Aging 2012, 33:195.e1-12.

63. Lu WY, Jackson MF, Bai D, Orser BA, MacDonald JF: In CA1 pyramidal neurons of the hippocampus protein kinase $C$ regulates calcium-dependent inactivation of NMDA receptors. J Neurosci 2000, 20:4452-4461.

64. Rebola N, Simões AP, Canas PM, Tomé AR, Andrade GM, Barry CE, Agostinho PM, Lynch MA, Cunha RA: Adenosine A2A receptors control neuroinflammation and consequent hippocampal neuronal dysfunction. J Neurochem 2011, 117:100-111.

65. Cristóvão-Ferreira S, Navarro G, Brugarolas M, Pérez-Capote K, Vaz SH, Fattorini G, Conti F, Lluis C, Ribeiro JA, McCormick PJ, Casadó V, Franco R, Sebastião AM: Modulation of GABA transport by adenosine A1R-A2AR heteromers, which are coupled to both Gs- and G(i/o)-proteins. J Neurosci 2011, 31:15629-15639.

66. Fredholm BB, IJzerman AP, Jacobson KA, Klotz KN, Linden J: International Union of Pharmacology. XXV. Nomenclature and classification of adenosine receptors. Pharmacol Rev 2001, 53:527-552.

67. Martineau M, Baux G, Mothet JP: D-serine signalling in the brain: friend and foe. Trends Neurosci 2006, 29:481-491.

68. Vargas Lopes C, Madeira C, Kahn SA, Albino Do Couto I, Bado P, Houzel JC, De Miranda J, De Freitas MS, Ferreira ST, Panizzutti R: Protein kinase C activity regulates D-serine availability in the brain. J Neurochem 2011, 116:281-290.

69. Fuchs $S A$, Berger $R$, de Koning TJ: D-serine: the right or wrong isoform? Brain Res 2011, 1401:104-117.

70. Rosenberg D, Artoul S, Segal AC, Kolodney G, Radzishevsky I, Dikopoltsev E, Foltyn VN, Inoue R, Mori H, Billard JM, Wolosker H: Neuronal D-serine and glycine release via the Asc- 1 transporter regulates NMDA receptor-dependent synaptic activity. J Neurosci 2013. In press.

71. Wolosker H: NMDA receptor regulation by D-serine: new findings and perspectives. Mol Neurobiol 2007, 36:152-164

72. Huang YY, Colino A, Selig DK, Malenka RC: The influence of prior synaptic activity on the induction of long-term potentiation. Science 1992, 255:730-733. 
73. Izumi Y, Clifford DB, Zorumski CF: Low concentrations of $N$-methyl-D-aspartate inhibit the induction of long-term potentiation in rat hippocampal slices. Neurosci Lett 1992, 137:245-248.

74. Soriano FX, Hardingham GE: Compartmentalized NMDA receptor signalling to survival and death. J Physiol 2007, 584:381-387.

75. Leveille F, El Gaamouch F, Gouix E, Lecocq M, Lobner D, Nicole O, Buisson A: Neuronal viability is controlled by a functional relation between synaptic and extrasynaptic NMDA receptors. FASEB J 2008, 22:4258-4271.

doi:10.1186/1742-2094-10-108

Cite this article as: Scianni et al:: Fractalkine $\left(\mathrm{CX}_{3} \mathrm{CL} 1\right)$ enhances hippocampal $\mathrm{N}$-methyl-D-aspartate receptor (NMDAR) function via D-serine and adenosine receptor type $A 2\left(A_{2 A} R\right)$ activity. Journal of Neuroinflammation 2013 10:108.

\section{Submit your next manuscript to BioMed Central and take full advantage of:}

- Convenient online submission

- Thorough peer review

- No space constraints or color figure charges

- Immediate publication on acceptance

- Inclusion in PubMed, CAS, Scopus and Google Scholar

- Research which is freely available for redistribution 